\title{
Quantification of the role of stabilized Criegee intermediates in the formation of aerosols in limonene ozonolysis
}

\author{
Yiwei Gong and Zhongming Chen \\ State Key Laboratory of Environmental Simulation and Pollution Control, College of Environmental Sciences and \\ Engineering, Peking University, Beijing 100871, China
}

Correspondence: Zhongming Chen (zmchen@pku.edu.cn)

Received: 20 July 2020 - Discussion started: 12 August 2020

Revised: 17 November 2020 - Accepted: 23 November 2020 - Published: 20 January 2021

\begin{abstract}
Stabilized Criegee intermediates (SCIs) have the potential to oxidize trace species and to produce secondary organic aerosols (SOAs), making them important factors in tropospheric chemistry. This study quantitatively investigates the performance of SCIs in SOA formation at different relative humidity (RH) levels, and the first- and secondgeneration oxidations of endo- and exocyclic double bonds ozonated in limonene ozonolysis are studied separately. Through regulating SCI scavengers, the yields and rate constants of SCIs in a reaction system were derived, and the quantities of SCIs were calculated. The quantity of SOAs decreased by more than $20 \%$ under low-humidity conditions ( $10 \% \mathrm{RH}-50 \% \mathrm{RH})$, compared to that under dry conditions, due to the reactions of SCIs with water, while the inhibitory effect of water on SOA formation was not observed under high-humidity conditions (60\% RH-90\% RH). When using excessive SCI scavengers to exclude SCI reactions, it was found that the effect of water on SOA formation with the presence of SCIs was different from that without the presence of SCIs, suggesting that SCI reactions were relevant to the non-monotonic impact of water. The fractions of the SCI contribution to SOAs were similar between dry and high-humidity conditions, where the SCI reactions accounted for $\sim 63 \%$ and $\sim 73 \%$ in SOA formation in the first- and second-generation oxidation; however, marked differences in SOA formation mechanisms were observed. SOA formation showed a positive correlation with the quantity of SCIs, and the SOA formation potential of SCIs under high-humidity conditions was more significant than that under dry and low-humidity conditions. It was estimated that $20 \%-30 \%$ of SCIs could be converted into SOAs under high-humidity conditions, while this value decreased
\end{abstract}

by nearly half under dry and low-humidity conditions. The typical contribution of limonene-derived SCIs to SOA formation is calculated to be $(8.21 \pm 0.15) \times 10^{-2} \mu \mathrm{g} \mathrm{m}^{-3} \mathrm{~h}^{-1}$ in forest, $(4.26 \pm 0.46) \times 10^{-2} \mu \mathrm{g} \mathrm{m}^{-3} \mathrm{~h}^{-1}$ in urban areas, and $(2.52 \pm 0.28) \times 10^{-1} \mu \mathrm{g} \mathrm{m}^{-3} \mathrm{~h}^{-1}$ in indoor areas. Water is an uncertainty in the role SCIs play in SOA formation, and the contribution of SCIs to SOA formation needs consideration even under high RH in the atmosphere.

\section{Introduction}

Stabilized Criegee intermediates (SCIs), formed from the stabilization of excited Criegee intermediates (ECIs) during the ozonolysis of alkenes, play important roles in atmospheric chemistry (Criegee and Wenner, 1949; Drozd and Donahue, 2011; Johnson and Marston, 2008; Khan et al., 2017; Ziemann and Atkinson, 2012). Although these reactive species have been known for decades, it is only recently that the synthesis and measurement of some simple SCIs has become possible (Sheps et al., 2014; Taatjes et al., 2008, 2013; Welz et al., 2012). SCIs can oxidize a series of trace species in the atmosphere, such as $\mathrm{SO}_{2}, \mathrm{NO}_{x}$, carboxylic acids, carbonyl compounds, or alcohols (Berndt et al., 2015; Elsamra et al., 2016; Khan et al., 2018; Mauldin et al., 2012; Taatjes et al., 2014), and the reaction rate constants reported in the last few years are several orders of magnitude larger than the values estimated earlier (Osborn and Taatjes, 2015; Sander, 2014; Taatjes, 2017), indicating that the contribution of SCIs to atmospheric oxidizing capacity should not be neglected. Reactions of SCIs are also important in secondary organic aerosol (SOA) formation because some bimolecular reac- 
tions of SCIs produce low-volatility products (ChhantyalPun et al., 2018; Kim et al., 2015; McGillen et al., 2017). In addition, SCIs are reported to participate in chain reactions with $\mathrm{RO}_{2}$ radicals and carboxylic acids, resulting in oligomer formation (Sakamoto et al., 2013; Zhao et al., 2015). The reaction pathways of SCIs in ozonolysis systems are complex, and it is difficult to determine the reaction mechanism of each pathway, especially for those complex SCIs such as monoterpene-derived SCIs. Although the important role of SCIs in aerosol formation has been claimed, a quantitative study of the contribution of SCIs to SOAs in alkene ozonolysis is lacking. Among the SCIs generated, the quantity of SCIs that participate in aerosol formation and the effects of experimental conditions remain unknown. These questions have not been investigated in detail, yet they are important for promoting our understanding of the fate of SCIs in alkene ozonolysis.

In the past years, many efforts have been devoted to studying the reaction mechanisms of SCIs. Some matters remain in dispute, and one of them is the effect of water. Through synthesizing and measuring SCIs containing fewer than three carbon atoms, it is found that the reaction of SCIs and water is structure-dependent, while the reaction mechanisms of more complex SCIs are still unclear because of the lack of synthesis and direct measurements (Huang et al., 2015; Lin and Chao, 2017). In addition to acting as a gas-phase sink of SCIs, water promotes the heterogeneous reactions of SCIs on aqueous surfaces (Enami and Colussi, 2017a; Kumar et al., 2018), which are purported to occur on the surfaces of droplets, aerosols, seas, etc. SCI reactions at airwater interfaces have drawn much attention in recent years because of the high reactivity of SCIs on aqueous surfaces, especially as applies to the large surface areas present in the atmosphere (Zhong et al., 2018). In the ozonolysis of alkenes, the presence of water changes the reaction pathways of SCIs, while the yields of products, such as peroxides and carbonyls, formed from SCI reactions with water have been reported to vary widely (Berndt et al., 2003; Huang et al., 2013; Li et al., 2016). Furthermore, the dependences of these products on relative humidity $(\mathrm{RH})$ have been a point of controversy (Anglada et al., 2002; Hasson et al., 2001, 2003; Ma et al., 2008; Tillmann et al., 2010). In an ozonolysis system examining the effects of the addition of compounds that could be oxidized by SCIs, the presence of water had different effects on the consumption of these added reactants (Newland et al., 2018; Sipilä et al., 2014; Ye et al., 2018). The reactions of SCIs with water further impact the generation of semi-volatile organic compounds (SVOCs) and lowvolatility organic compounds (LVOCs), resulting in changes in SOA yield and composition. It is intriguing to note that previous studies presented positive, negative, and neutral effects of water on aerosol formation in alkene ozonolysis (Bonn et al., 2002; Bracco et al., 2019; von Hessberg et al., 2009; Jonsson et al., 2008; Li et al., 2019; Warren et al., 2009; Yu et al., 2011), indicating that the uncertainty and complexity of SOA formation as RH changes need further research.

Previous studies have mainly chosen smog chambers as reaction equipment, yet the long reaction time and the large wall loss may significantly affect the analysis results (Chuang and Donahue, 2017; Zhang et al., 2014, 2015). As reported by Brune (2019), the Chamber Wall Index, which could be used to evaluate the degree that walls alter the chemistry, demonstrates that the wall effect in flow reactors is smaller than that in chambers. In this study, experiments were carried out in flow tube reactors to constrain the reaction time to within a few minutes, with the hope of reducing the wall loss effect and allowing for observation of the products generated in the initial state of the reaction. Limonene is selected as the model compound for this research, not only because of the large emissions of limonene from both biogenic and anthropogenic sources (Andersson-Sköld and Simpson, 2001; Atkinson and Arey, 2003) but also because of the high SOA formation potential of limonene as a double-unsaturated terpene (Lee et al., 2006; Ng et al., 2006). This study focuses on quantifying the impact of SCIs on aerosol formation at different RH levels, and SCI scavengers are used to control the quantities of SCIs in the reaction system. In order to have a complete understanding of limonene-derived SCIs, our research strategy consisted of two sets of experiments, which separately investigated the first-generation oxidation with ozonated endocyclic double bonds (endo-DBs) and the second-generation oxidation with ozonated exocyclic double bonds (exo-DBs).

\section{Experimental}

\subsection{Apparatus and procedures}

One-stage and two-stage apparatuses were used to investigate SOA formation in the first- and secondgeneration oxidations, respectively. Limonene ozonolysis primarily took place on endo-DBs, with a rate constant of $2 \times 10^{-16} \mathrm{~cm}^{3}$ molec. $^{-1} \mathrm{~s}^{-1}$ (Atkinson, 1990; Shu and Atkinson, 1994), and the exo-DB reaction with $\mathrm{O}_{3}$ was about 30 times slower (Pathak et al., 2012). In the first set of experiments focusing on the first-generation oxidation, we used an $8 \mathrm{~L}$ quartz flow tube reactor $(2 \mathrm{~m}$ length, $70 \mathrm{~mm}$ inner diameter), which was equipped with a water jacket to control the reaction temperature at $298.0 \pm 0.5 \mathrm{~K}$. Gas containing limonene was generated with a diffusion tube kept at a specific temperature, and the concentration of limonene was detected to be $90.0 \pm 1.5$ ppbv by a gas chromatograph with a flame ionization detector (Agilent 7890A GC, USA). $\mathrm{O}_{3}$ was generated through photolysis of pure oxygen with a low-pressure $\mathrm{Hg}$ lamp, and the concentration of $\mathrm{O}_{3}$ was detected to be $270.0 \pm 3.0 \mathrm{ppbv}$ by indigo disulfonate spectrophotometry. To avoid disturbance by $\mathrm{OH}$ radicals, excessive 2-butanol was generated with a bubbler and added to 
the reactor as an $\mathrm{OH}$ scavenger. The concentration of 2butanol was $300.0 \pm 6.0 \mathrm{ppmv}$ and was estimated to be sufficient for scavenging more than $99 \%$ of $\mathrm{OH}$ radicals. Acetic acid (AA), which has been considered an efficient SCI scavenger due to the rapid reaction of SCIs with AA (Ahmad et al., 2017; Yao et al., 2014), was used as an SCI scavenger in this study. Gas containing AA was prepared by an evacuated steel canister (15 L, Entech Instruments), of which the outlet was linked with a mass flow controller to regulate the gas flow rate. Water vapor was produced by passing $\mathrm{N}_{2}$ or $\mathrm{O}_{2}$ through a water bubbler, and the $\mathrm{RH}$ in the reactor ranged from dry conditions $(<0.5 \% \mathrm{RH})$ to $90 \pm 3 \% \mathrm{RH}$. Chemicals used in this study are shown in the Supplement. Gases containing limonene, $\mathrm{O}_{3}, 2$-butanol, $\mathrm{AA}$, and water vapor were rapidly blended in a mixing ball and successively introduced into the flow tube reactor. The total gas flow rate was $2 \mathrm{slpm}$ and the residence time was $240 \mathrm{~s}$. In the first set of experiments, endo-DBs consumed by $\mathrm{O}_{3}$ was estimated to be $\sim 24.6 \mathrm{ppbv}$, while exo-DB ozonolysis was not taken into account.

In the second set of experiments focusing on the secondgeneration oxidation, we used two-stage apparatus including a $2 \mathrm{~L}$ quartz flow tube reactor ( $1 \mathrm{~m}$ length, $50 \mathrm{~mm}$ inner diameter) and an $8 \mathrm{~L}$ quartz flow tube reactor $(2 \mathrm{~m}$ length, $70 \mathrm{~mm}$ inner diameter) in series. The experiments were performed at $298.0 \pm 0.5 \mathrm{~K}$ in the dark, and the diagram of the reaction equipment is shown in Fig. 1. To investigate the exo$\mathrm{DB}$ oxidation alone a key point was separating the endo-DB reaction, so the major role of the first stage was to accomplish the reaction of endo-DBs with $\mathrm{O}_{3}$. Although it was unavoidable that some exo-DBs also reacted with $\mathrm{O}_{3}$ in the first stage, this would not impact the analysis of the secondgeneration oxidation in the second stage because the quantitative investigation only focused on the exo-DB ozonated in the second-stage. The initial concentration of limonene in the first stage was $46.2 \pm 1.0 \mathrm{ppbv}$, and the concentration of $\mathrm{O}_{3}$ was $12.2 \pm 0.3$ ppmv. Excessive 2-butanol was added to scavenge $\mathrm{OH}$ radicals. With a total flow rate of $1.95 \mathrm{slpm}$, the residence time in the first stage was $65 \mathrm{~s}$ and the remaining limonene was estimated to be less than $0.4 \mathrm{ppbv}$. Before entering the second reactor, gas containing different concentrations of AA was added to mix with the gas out of the first reactor. The total flow rate in the second stage was $2 \mathrm{slpm}$, and it was estimated that the quantity of exo-DBs that was ozonated was $\sim 15.2 \mathrm{ppbv}$. Assuming a typical $24 \mathrm{~h}$ average ambient $\mathrm{O}_{3}$ concentration of 30.0 ppbv (Palm et al., 2018), the equivalent atmospheric times of $\mathrm{O}_{3}$ exposure in the firstand second-generation oxidations were 0.6 and $26.4 \mathrm{~h}$, respectively.

\subsection{Measurements}

To detect the concentration of AA, gas samples out of the reactor were collected in a glass coil collector rinsed by ultrapure water $(18 \mathrm{M} \Omega)$ at $277 \mathrm{~K}$. The effective length of the coil collector was $\sim 100 \mathrm{~cm}$, in which the flow rates of gas and water were $0.9 \mathrm{slpm}$ and $0.2 \mathrm{~mL} \mathrm{~min}^{-1}$, respectively. The coil collector, shown as a diagram in the Supplement, was as elaborated before (Hua et al., 2008), and the percentage of AA dissolved in the rinsing solution was calculated to be higher than $99 \%$ based on Henry's law when the partitioning between the gas phase and the liquid phase was at equilibrium (Lazrus et al., 1986). Samples of extracting solution were analyzed by ion chromatography (IC; Dionex ICS-2000) with a detection limit of $\sim 50 \mathrm{pptv}$, and the standard solution of AA was prepared to perform calibrations in every measurement. Wall loss experiments were carried out by introducing gas containing AA to the reactor at 2 slpm, and the inlet and outlet concentrations of AA at different RH levels were measured. The loss fraction of AA in the $8 \mathrm{~L}$ flow tube was found to be less than $8 \%$ without distinct influence by $\mathrm{RH}$, and the results reported below were rectified by the wall loss effect. In both of the first- and second-generation oxidations, when no AA was added, the background level of AA was detected to be less than $1.0 \mathrm{ppbv}$, which was subtracted from the results.

Particle size distribution was measured by a scanning mobility particle sizer (SMPS 3938, TSI) consisting of a differential mobility analyzer (DMA 3081A) and a condensation particle counter (CPC 3776). The measurement was in the range of $13.8-504.8 \mathrm{~nm}$, and the interval was $5 \mathrm{~min}$. The sampling flow rate of SMPS was $0.3 \mathrm{~L} \mathrm{~min}^{-1}$, and the sheath airflow was $3 \mathrm{~L} \mathrm{~min}^{-1}$. All data were treated with multiple charge correction and diffusion loss correction by TSI software, and the aerosol density was assumed to be $1.3 \mathrm{~g} \mathrm{~cm}^{-3}$ when calculating the aerosol mass concentration (Saathoff et al., 2009; Wilson et al., 2015). The gas flow in the $8 \mathrm{~L}$ flow reactor was evaluated to be laminar as the Reynolds number was $\sim 43$ (Ezell et al., 2010), and to better observe the process of SOA formation during the reaction, a stainless tube, which was flexible in the axial direction, was used to collect samples at different positions in the reactor. As the gas sample extracted from the stainless-steel tube was a small part of the total gas flow, the whole flow state in the reactor could remain stable. The gas samples collected at different positions represented products formed under different reaction times. The measurement of the SOA formation process in the $8 \mathrm{~L}$ flow reactor started after the reaction had proceeded for $60 \mathrm{~s}$, and the sampling interval was set as $30 \mathrm{~s}$. It was noted that this method was used to assist us to know the processes of SOA formation in the first- and second-generation oxidation. The calculations and analysis in this study used the samples collected at the end of the reactor. The aerosol wall loss experiments were performed as in our previous study (Gong et al., 2018), and the loss fraction of SOA mass concentration was found to increase when $\mathrm{RH}$ increased as shown in Table S1. The mass concentration of SOA was also subtracted by the water content according to the hygroscopic growth factor reported before (Bateman et al., 2015). 
(a) One-stage equipment

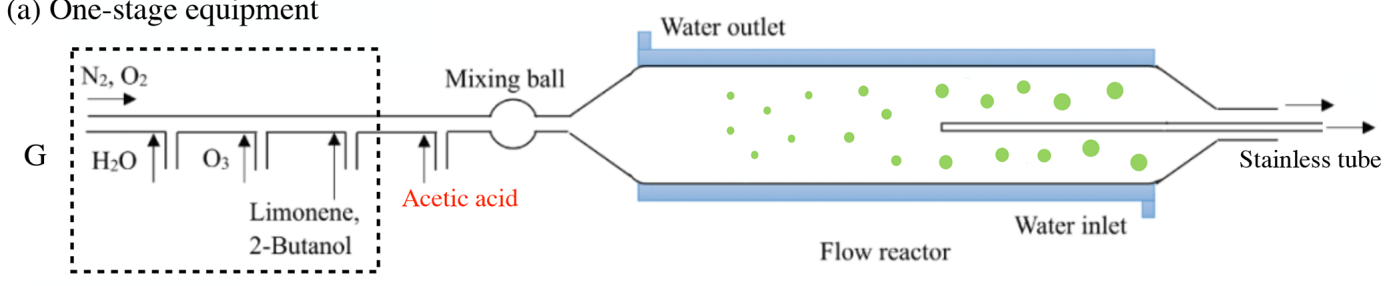

(b) Two-stage equipment

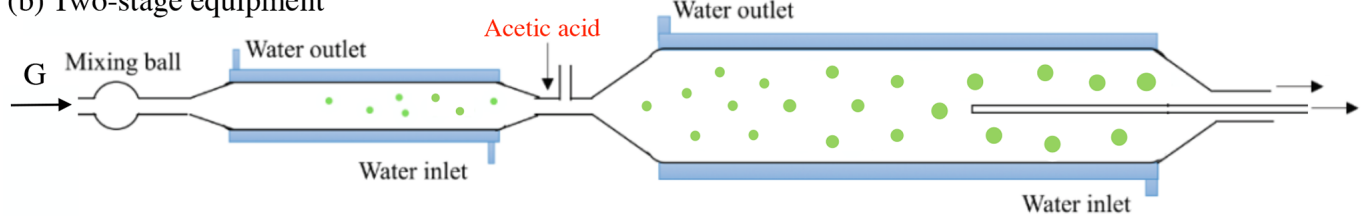

Figure 1. Diagram of the experimental setup. The (a) one-stage and (b) two-stage apparatuses are used to investigate the first- and secondgeneration oxidation. The green circles represent the process of SOA growth.

\section{Results and discussion}

\subsection{Regulating and quantifying the amount of SCIs}

To quantitatively investigate the performance of SCIs in SOA formation, the quantity of SCIs in the reaction system was regulated by adding different concentrations of AA (24$480 \mathrm{ppbv})$ at a series of RH levels $(<0.5 \%, 10 \%, 40 \%$, $60 \%, 80 \%)$. Both AA and water could react with SCIs, and here the quantity of SCIs in the reaction system is defined as the accumulated quantity of SCIs that are not consumed by AA and water, and it could be derived by deducting the quantity of SCIs reacted with AA and water from the amount of total SCIs generated. Limonene ozonolysis generates several kinds of SCIs (Leungsakul et al., 2005), which are difficult to distinguish. As reported before, SCIs' reaction with water is structure-dependent, and here all SCIs are divided into two types, one of which tends to react with water $\left(\mathrm{SCI}_{\mathrm{I}}\right)$ and the other of which is inert to reacting with water ( $\left.\mathrm{SCI}_{\mathrm{II}}\right)$ (Long et al., 2018). The molar yield of SCIs, defined as the ratio of SCI mole number to the mole number of ozonated DB, could be inferred through measuring the consumption of AA $(\triangle \mathrm{AA})$. This calculation was based on two points: first, previous studies reported that SCIs' reaction with AA was rapid and not structure-dependent (Khan et al., 2018); second, as we describe below, the SCI yield derived from reaction with AA was higher than that derived from reaction with water, confirming that both kinds of limonene-derived SCIs reacted effectively with AA. With the increase in AA concentration, $\triangle \mathrm{AA}$ increased in the beginning and then became stable. According to the maximum $\triangle \mathrm{AA}$ under dry conditions, the SCI yield of ozonated endo-DBs was calculated to be $\sim 0.44$. Through measuring the generation of $\mathrm{H}_{2} \mathrm{O}_{2}$ (in the Supplement), the yield of $\mathrm{SCI}_{\mathrm{I}}$ in ozonated endo-DBs was reported to be $\sim 0.24$ (Gong et al., 2018), and thus the yield of $\mathrm{SCI}_{\mathrm{II}}$ was derived to be $\sim 0.20$.

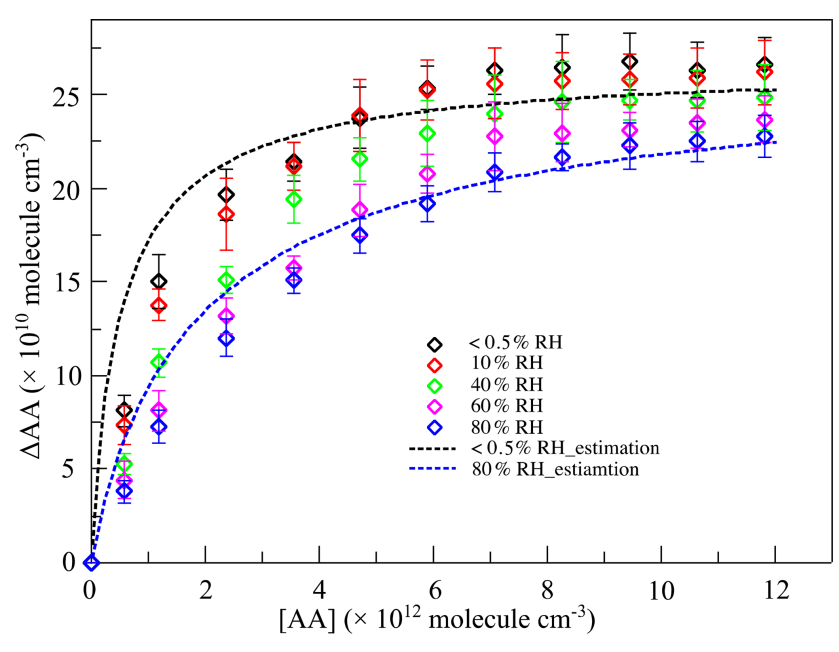

Figure 2. The variations of the consumption of acetic acid $(\triangle \mathrm{AA})$ with the concentration of acetic acid ([AA]) at different relative humidity $(\mathrm{RH})$ levels in the first-generation oxidation. Scatters: measured $\triangle \mathrm{AA}$; black line: estimated $\triangle \mathrm{AA}$ at $<0.5 \% \mathrm{RH}$; blue line: estimated $\triangle \mathrm{AA}$ at $80 \% \mathrm{RH}$.

For the quantity of SCIs consumed by SCI scavengers, $\triangle \mathrm{AA}$ represented the quantity of SCIs consumed by AA, and the quantity of SCIs consumed by water was calculated through the reaction rate ratio of SCIs' reaction with water and AA, which is elaborated in the Supplement. The ratio of rate constants of SCIs' reaction with water and AA was derived from the estimation of $\triangle \mathrm{AA}$ as shown in Fig. 2. Due to the competition with water, the variation in $\triangle \mathrm{AA}$ under highhumidity conditions was gentler than that under dry conditions. The relationship between $\triangle \mathrm{AA}$ and the concentration of AA is estimated according to Eqs. (1) to (3) (Bracco et al., 2019; von Hessberg et al., 2009): 


$$
\begin{aligned}
& \frac{\mathrm{SCI}_{\mathrm{AA}}}{\mathrm{SCI}_{\mathrm{Total}}}=\frac{\Delta \mathrm{AA}}{\mathrm{SCI}_{\mathrm{Total}}} \\
& =\frac{k_{(\mathrm{SCI}+\mathrm{AA})} \cdot[\mathrm{AA}]}{k_{(\mathrm{SCI}+\mathrm{AA})} \cdot[\mathrm{AA}]+k_{\left(\mathrm{SCI}+\mathrm{H}_{2} \mathrm{O}\right)} \cdot\left[\mathrm{H}_{2} \mathrm{O}\right]+k_{(\mathrm{other})}}, \\
& \Delta \mathrm{AA}=\frac{1}{1+\frac{k_{\left(\mathrm{SCl}+\mathrm{H}_{2} \mathrm{O}\right)} \cdot\left[\mathrm{H}_{2} \mathrm{O}\right]+k_{\text {(other })}}{k_{(\mathrm{SCI}+\mathrm{AA}) \cdot[\mathrm{AA}]}}} \cdot \mathrm{SCI}_{\mathrm{Total}},
\end{aligned}
$$

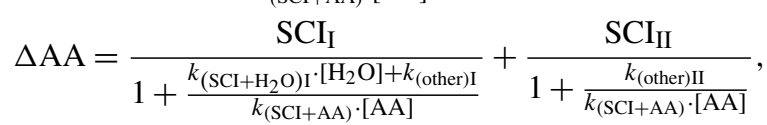

where $\mathrm{SCI}_{\mathrm{AA}}\left(\right.$ molec. $\left.\mathrm{cm}^{-3}\right)$ is the quantity of SCIs reacted with AA; $\mathrm{SCI}_{\text {Total }}\left(\right.$ molec. $\left.\mathrm{cm}^{-3}\right)$ is the quantity of total SCIs generated; $\triangle \mathrm{AA}\left(\right.$ molec. $\left.\mathrm{cm}^{-3}\right)$ is the amount of AA consumed; $k_{(\mathrm{SCI}+\mathrm{AA})}\left(\mathrm{cm}^{3}\right.$ molec. $\left.{ }^{-1} \mathrm{~s}^{-1}\right)$ is the rate constant of SCIs' reaction with AA; [AA] $\left(\right.$ molec. $\left.\mathrm{cm}^{-3}\right)$ is the concentration of $\mathrm{AA} ; k_{\left(\mathrm{SCI}+\mathrm{H}_{2} \mathrm{O}\right)}\left(\mathrm{cm}^{3}\right.$ molec. $\left.^{-1} \mathrm{~s}^{-1}\right)$ is the rate constant of SCIs' reaction with $\mathrm{H}_{2} \mathrm{O} ;\left[\mathrm{H}_{2} \mathrm{O}\right]\left(\right.$ molec. $\mathrm{cm}^{-3}$ ) is the concentration of $\mathrm{H}_{2} \mathrm{O}$; and $k_{\text {(other) }}=k_{\text {(isomerization) }}+$ $k_{\text {(SCI+products) }} \times$ [products], meaning that $k_{\text {(other) }}$ accounts for the sum of SCIs' isomerization and reaction with other products in the system. Equation (2) could be extended to Eq. (3) containing two types of SCIs. One consideration in calculations is whether the reaction with $\mathrm{H}_{2} \mathrm{O}$ or with $\left(\mathrm{H}_{2} \mathrm{O}\right)_{2}$ dominates in the $\mathrm{SCI}_{\mathrm{I}}$ reaction with water, which is discussed in the Supplement. Results showed that the reaction with $\mathrm{H}_{2} \mathrm{O}$ was more important in this reaction system, and the values of $k_{\left(\mathrm{SCI}+\mathrm{H}_{2} \mathrm{O}\right) \mathrm{I}}$ and $k_{(\mathrm{other}) \mathrm{I}}$ were derived to be $5 \times 10^{-16} \mathrm{~cm}^{3}$ molec. $^{-1} \mathrm{~s}^{-1}$ and $30 \mathrm{~s}^{-1}$ (Fig. S2). Estimations of $\triangle \mathrm{AA}$ at $<0.5 \% \mathrm{RH}$ and $80 \% \mathrm{RH}$ were calculated and are shown in Fig. 2 , where $k_{(\mathrm{SCI}+\mathrm{AA})}$ and $k_{(\text {other)II }}$ are derived to be $1 \times 10^{-10} \mathrm{~cm}^{3}$ molec. $^{-1} \mathrm{~s}^{-1}$ and $100 \mathrm{~s}^{-1}$, respectively. The ratio of rate constants of SCIs' reaction with water and AA was $5 \times 10^{-6}$, and the quantities of SCIs under different conditions are shown in Table S2.

In the second-generation oxidation, according to the maximum $\triangle \mathrm{AA}$ under dry conditions, the SCI yield of ozonated exo-DBs was calculated to be $\sim 0.60$. As RH increased to $40 \%, \Delta$ AA became smaller than that under dry conditions because of the competition of water. However, at $60 \% \mathrm{RH}$, $\triangle \mathrm{AA}$ performed a rise and at $80 \% \mathrm{RH}$ the maximum of $\triangle \mathrm{AA}$ increased to be about double that under dry conditions, suggesting that more SCIs were generated due to more ozonated exo-DBs. The quantity of exo-DBs ozonated under high-humidity conditions could be derived through estimating the variation in $\triangle \mathrm{AA}$. Through calculating the formation of $\mathrm{H}_{2} \mathrm{O}_{2}$ as described above, the yields of $\mathrm{SCI}_{\mathrm{I}}$ and $\mathrm{SCI}_{\mathrm{II}}$ in the second-generation oxidation were both assumed to be 0.30 . According to the calculation results (Fig. S3), the quantities of exo-DBs ozonated at $60 \% \mathrm{RH}$ and $80 \% \mathrm{RH}$ were 1.3 and 2.0 times that under dry conditions. If particles were treated as liquid state under high-humidity conditions, the amount of exo-DB reaction with $\mathrm{O}_{3}$ in aerosols was calculated and is shown in the Supplement. Bulk-phase ozonoly- sis could not explain the ozonated exo-DB, suggesting that reactions on surfaces were more important. Some studies reported the uptake and ozonation of terpenes on aqueous surfaces (Enami et al., 2010; Matsuoka et al., 2017), and as for those semi-volatile products containing exo-DBs, their uptake on aqueous surfaces might have a greater chance of happening due to the lower volatility. This study reported direct evidence for the heterogeneous oxidation of exo-DB of limonene, which was proposed before by Zhang et al. (2006). The uptake coefficient of these unsaturated products was estimated to be of $10^{-3}$ magnitude, which is elaborated in the Supplement. The quantities of SCIs in the second stage under different conditions were calculated and appear in Table S3.

\subsection{The effect of water on SOA formation}

\subsubsection{Water effect with the presence of SCIs}

In ozonolysis water could participate in some reactions, and it is necessary to investigate SOA formation under different RH levels. When investigating the SOA formation process, experiments were carried out from $<0.5 \% \mathrm{RH}$ to $90 \%$ RH with an interval of $10 \% \mathrm{RH}$. Through calculating the amounts of limonene reacted at different reaction times, the growth curves of SOA mass concentration and SOA yield could be derived in the first-generation oxidation, as shown in Fig. S4. SOA yield was determined from the mass concentration of SOAs divided by the mass concentration of limonene reacted. As RH increased, SOA formation presented non-monotonic dependence on $\mathrm{RH}$. The presence of water suppressed the process of SOA formation under low-humidity conditions (10\% RH-50\% RH), while the inhibitory effect of water on SOA formation was not observed under high-humidity conditions (60\% RH-90\% RH). The SOA yields at the end of the first-generation oxidation under dry and high-humidity conditions were $\sim 20 \%$, and under low-humidity conditions the SOA yield was $\sim 15 \%$. In the second-generation oxidation, SOA growth was observed due to exo-DB ozonolysis, and the increase in SOA mass concentration $(\triangle \mathrm{SOA})$ was derived by subtracting the SOA mass concentration at the end of the first stage from that at the end of the second stage. Because limonene was almost consumed in the first stage, the variations in SOA mass concentration and SOA yield in the second stage are shown as a function of reaction time (Fig. S5). The inhibitory effect of water on SOA formation under low-humidity conditions was also observed with a $\triangle \mathrm{SOA}$ reduction of as much as $\sim 22 \%$. Under high-humidity conditions, SOA growth became more intense due to more ozonated exo-DB, and the increment of SOA yield above $80 \%$ RH was more than twice that under dry conditions. 


\subsubsection{Water effect without the presence of SCIs}

To figure out the fraction of SCI reactions contributing to SOA formation, excess AA $(10.0 \pm 0.4 \mathrm{ppmv})$ was added to scavenge all SCIs in the reaction system. The concentration of AA used here was estimated to be sufficient for scavenging more than $99 \%$ of SCIs generated during reactions as claimed in the Supplement. Without the presence of SCIs, the quantity of SOAs decreased dramatically in both the firstand the second-generation oxidation, indicating that the reaction with AA converted SCIs into more volatile products. The mechanisms of SCIs' reaction with carboxylic acids were not entirely clear, and two reaction pathways were proposed. The insertion products, produced from the hydroperoxyester channel, went through water elimination and formed acid anhydride (Aplincourt and Ruiz-Loìpez, 2000; Cabezas and Endo, 2020; Long et al., 2009). As the molecular weight of AA was small, the contribution of acid anhydride produced to SOAs might be limited. Some studies suggested that SCIs' reaction with acids proceeded via acid-catalyzed tautomerization of SCIs to vinyl hydroperoxides, which were not likely to contribute to aerosols (Kumar et al., 2014a; Liu et al., 2015). Besides, it was observed that when scavenging the same quantity of SCIs by AA and water, the decreases in SOAs were similar. Thus, it was estimated that the contribution of the products formed from SCIs' reaction with AA to aerosols was small. Through excluding the impact of SCIs, it was found that SCI reactions accounted for $\sim 63 \%$ and $\sim 73 \%$ of the total SOAs formed under dry conditions in the first- and second-generation oxidation.

Figure 3 shows how the presence of SCIs impacts SOA formation, and the influence of water on SOA formation with the presence of SCIs was different from that without the presence of SCIs. The inhibitory effect of water on SOA formation could be attributed to the reaction between SCIs and water, producing $\alpha$-hydroxyalkyl hydroperoxides, which were thought to preferentially decompose into $\mathrm{H}_{2} \mathrm{O}_{2}$ and aldehydes (Chen et al., 2016; Jiang et al., 2013; Kumar et al., 2014b; Winterhalter et al., 2000). The aldehydes, such as pinonaldehyde and nopinone formed from $\alpha$-pinene-derived and $\beta$ pinene-derived SCIs' reaction with water, displayed higher volatility, and their contribution to aerosols was reported to be small in ozonolysis (Emanuelsson et al., 2013; Fick et al., 2003; Jenkin, 2004; Mutzel et al., 2016; Sakamoto et al., 2017). An intriguing finding here was that the quantity of SOAs formed under high-humidity conditions increased, and one possible reason for this phenomenon was the physical effect of water, as the viscosity of particles would decrease due to the uptake of water, resulting in the transition of particles from non-liquid to liquid state with increasing RH (Faust et al., 2017; Renbaum-Wolff et al., 2013). The low viscosity of particles further improved the particle-phase diffusion and gas-particle partitioning of SVOCs (Shiraiwa and Seinfeld, 2012; Ye et al., 2016). Nevertheless, some studies have reported that the SOA formation process in monoter- pene ozonolysis is quasi-equilibrium growth, meaning that the timescales of gas-particle partitioning equilibrium and diffusion in particles are much smaller than the timescales of gas-phase reactions and the wall loss process (McVay et al., 2014, 2016; Nah et al., 2016, 2017; Riipinen et al., 2011). Results showed that when SCIs were scavenged in the first-generation oxidation, the quantity of SOAs was almost unaffected by RH. Besides, consider that the diameters of most particles generated in the experiments were smaller than $100 \mathrm{~nm}$ and the effect of water on the diffusion limit was not considered the major cause of the increase in SOAs under high-humidity conditions (Tu and Johnson, 2017; Veghte et al., 2013). Figure 4 shows the dependence of the fraction of SCIs' contribution to SOA on RH, and it was found that in both of the first- and second-generation oxidations, the contribution of SCI reactions to SOA formation decreased under low-humidity conditions and increased under high-humidity conditions, suggesting that the non-monotonic effect of water on SOA formation was relevant to SCI reactions.

\subsection{The correlation between SCIs and SOA formation}

\subsubsection{Quantifying the fraction of SCIs converting into SOAs}

The variation in SOAs with the concentration of AA at different RH levels in the first-generation oxidation is shown in Fig. 5. Although the quantity of SOAs formed under dry and high-humidity conditions were similar, their variations were different with increasing AA, indicating that differences existed in SOA formation mechanisms between dry and high-humidity conditions. To figure out the correlation between SCIs and SOA formation, the dependence of SOA mass concentration on the quantity of SCIs is shown in Fig. 6, where the dependences under dry and low-humidity conditions are similar to each other with the deviation among their slopes of linear fitting lines falling within $15 \%$. The fitting lines under high-humidity conditions are also similar. The fact that the correlation coefficients ( $R^{2}$ values) of the fitting lines are greater than 0.9 indicates that the quantity of SOAs generated has a significant positive correlation with the quantity of SCIs, regardless of RH and oxidation degree. In the first-generation oxidation, the slope of the fitting line under dry and low-humidity conditions is $6.26 \times 10^{-11}$ and the slope under high-humidity conditions is $1.05 \times 10^{-10}$. In the second-generation oxidation, the slope of the fitting line under dry and low-humidity conditions is $5.08 \times 10^{-11}$ and the slope of the fitting line at $60 \% \mathrm{RH}$ is $9.43 \times 10^{-11}$, which is similar to the value of $1.08 \times 10^{-10}$ at $80 \% \mathrm{RH}$. The slopes of fitting lines in the first- and second-generation oxidations under dry and low-humidity conditions were similar, as were the fitting results under high-humidity conditions, suggesting that the role of SCIs in SOA formation was slightly affected by the oxidation degree in limonene ozonolysis. Based on the correlation between SOA formation and 

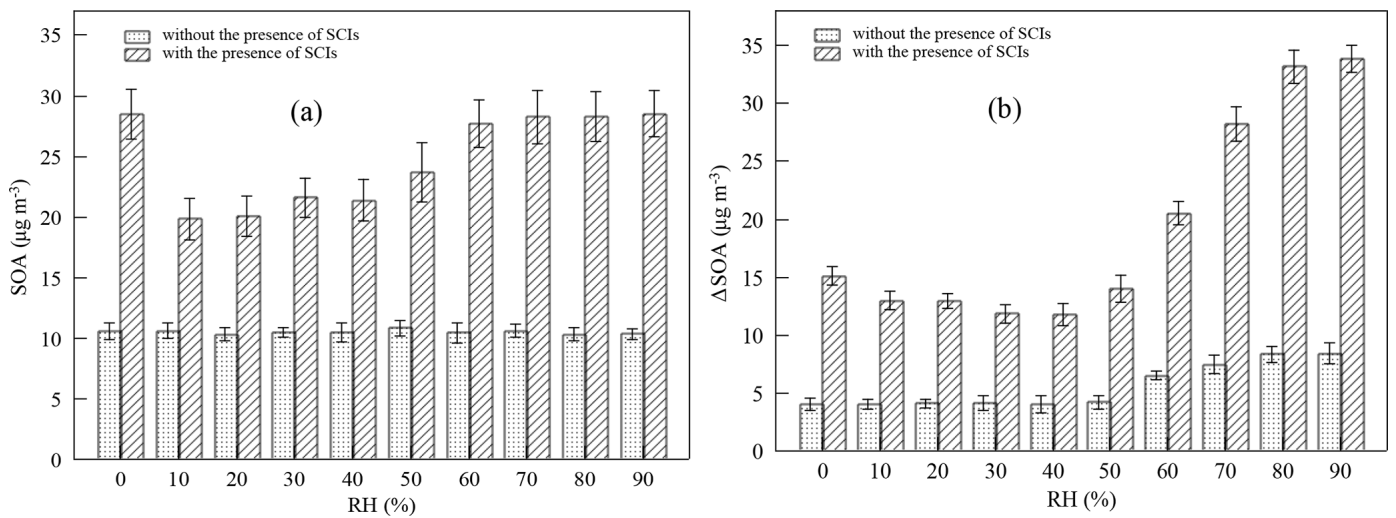

Figure 3. Impact of the presence of SCIs on (a) SOA mass concentration (SOA) in the first-generation oxidation and (b) the increment of SOA mass concentration $(\triangle \mathrm{SOA})$ in the second-generation oxidation at different relative humidity $(\mathrm{RH})$ levels.

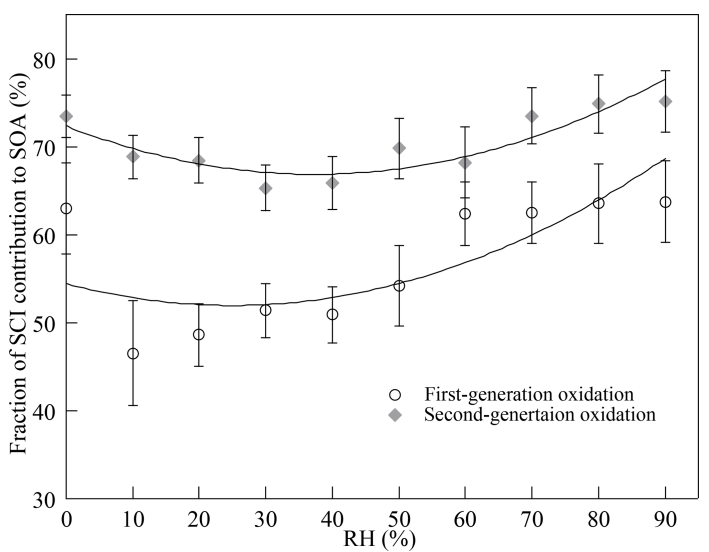

Figure 4. The fraction of SCI reactions contributing to SOA formation in the (a) first- and (b) second-generation oxidation at different relative humidity $(\mathrm{RH})$ levels.

SCIs, the SOA yield of limonene-derived SCIs could be inferred from the mass concentration of SOAs formed from SCI reactions divided by the mass concentration of SCIs reacted. The SOA yield of limonene-derived SCIs was estimated to be $\sim 0.20$ under dry and low-humidity conditions and $\sim 0.35$ under high-humidity conditions. From another view, results showed that among the SCIs in the reaction system, the fraction that could produce low-volatility products and convert into SOAs was stable, and here the fraction was denoted as $\alpha_{\mathrm{SCI}}$. In this study $\alpha_{\mathrm{SCI}}$ of limonene-derived SCIs was estimated to be $11 \%-17 \%$ under dry and low-humidity conditions and $20 \%-30 \%$ under high-humidity conditions, which is elaborated in the Supplement. Considering that part of the products in particles was semi-volatile, $\alpha_{\mathrm{SCI}}$ derived here was expected to be a lower limit, and this value was used to estimate the quantity of SOAs formed from SCI reactions.

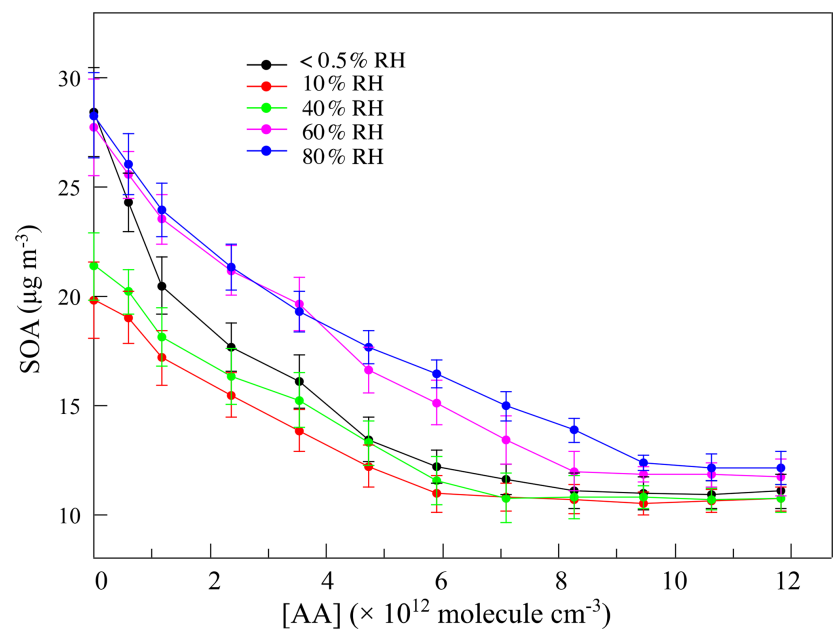

Figure 5. The variation in SOA mass concentration (SOA) with the concentration of acetic acid ([AA]) at different relative humidity (RH) levels in the first-generation oxidation.

\subsubsection{Analysis on reaction mechanisms}

The SOA formation potential of SCIs under high-humidity conditions was found to be more significant than that under dry and low-humidity conditions, which needed explanations about reaction mechanisms. In ozonolysis the cycloaddition of $\mathrm{O}_{3}$ to alkenes produced a primary ozonide (POZ), which decomposed into ECIs and aldehyde or ketone. ECIs can isomerize through the hydroperoxide channel, rearrange into esters, or stabilize to form SCIs (Johnson and Marston, 2008). In this study, SOA formation was roughly divided into two pathways: directly from ECI reactions and from SCI reactions. According to the results, SOA formation directly from ECI reactions was unaffected by changing RH. As for SCIs, the main reaction pathways concluded with bimolecular reactions with products formed during ozonolysis (Lee and Kamens, 2005; Yao et al., 2014); unimolecular reactions pro- 
ducing vinyl hydroperoxides, secondary ozonides, and dioxiranes, etc. (Long et al., 2019); and chain reactions producing oligomers (Sakamoto et al., 2013). The reaction scheme of limonene ozonolysis and the structures of proposed products are shown as Fig. 7. When discussing the behaviors of SCIs in SOA formation, side reactions of SCIs needed consideration and are analyzed below.

Since the concentration of $\mathrm{O}_{3}$ in experiments was higher than the concentration of limonene, the reaction of SCIs with $\mathrm{O}_{3}$ might impact product formation. A lower limit for the rate constant of SCIs' reaction with $\mathrm{O}_{3}$ of $10^{-18} \mathrm{~cm}^{3}$ molec. ${ }^{-1} \mathrm{~s}^{-1}$ was proposed at $298 \mathrm{~K}$ (Kjaergaard et al., 2013), and some studies derived a higher value of about $10^{-14} \mathrm{~cm}^{3}$ molec. ${ }^{-1} \mathrm{~s}^{-1}$ (Chang et al., 2018; Vereecken et al., 2015). The reaction of limonene-derived SCIs and $\mathrm{O}_{3}$ was rarely reported, and we took the rate constant of $10^{-14} \mathrm{~cm}^{3}$ molec. ${ }^{-1} \mathrm{~s}^{-1}$ to estimate an upper limit for the quantity of SCIs reacted with $\mathrm{O}_{3}$. Taking SCIs' reaction with $\mathrm{AA}$ as a reference, when using the lowest concentration of $\mathrm{AA}$ in experiments, the ratios of the quantity of SCIs reacted with $\mathrm{O}_{3}$ to the quantity of SCIs reacted with AA were 0.001 and 0.046 in the first- and secondgeneration oxidation, respectively, indicating that the reaction of SCIs with $\mathrm{O}_{3}$ was not important. SCIs could react with alcohols, and here the effect of this reaction was considered because in this study a high concentration of 2butanol was used to scavenge $\mathrm{OH}$ radicals. Previous studies reported that as for the reactions of SCIs with alcohols, the substitution group of alcohols had little effect on the reactions, while the structures of SCIs showed an obvious influence. The rate constants of the $\mathrm{CH}_{2} \mathrm{OO}$ reaction with alcohols were about $10^{-13} \mathrm{~cm}^{3}$ molec. ${ }^{-1} \mathrm{~s}^{-1}$ at $298 \mathrm{~K}$ (Tadayon et al., 2018), and it was slower for the $\left(\mathrm{CH}_{3}\right)_{2} \mathrm{COO}$ reaction with alcohols, whose rate constants were reported to be $10^{-15}-10^{-14} \mathrm{~cm}^{3}$ molec. ${ }^{-1} \mathrm{~s}^{-1}$ (Aroeira et al., 2019; McGillen et al., 2017). Watson et al. (2019) computed that the rate constant of syn- $\mathrm{CH}_{3} \mathrm{CHOO}+\mathrm{CH}_{3} \mathrm{OH}$ was about $10^{-17} \mathrm{~cm}^{3}$ molec. ${ }^{-1} \mathrm{~s}^{-1}$, which was much smaller than that of about $10^{-12} \mathrm{~cm}^{3}$ molec. ${ }^{-1} \mathrm{~s}^{-1}$ for anti$\mathrm{CH}_{3} \mathrm{CHOO}+\mathrm{CH}_{3} \mathrm{OH}$ at $298 \mathrm{~K}$. In limonene ozonolysis, several kinds of SCIs were produced, and their structures are shown in Fig. S7. Mono-substituted SCIs and di-substituted SCIs were formed from endo-DB ozonolysis, and exo-DB ozonolysis produced $\mathrm{CH}_{2} \mathrm{OO}$ and di-substituted SCIs. When assuming the rate constant of SCIs' reaction with 2-butanol as $10^{-14} \mathrm{~cm}^{3}$ molec. ${ }^{-1} \mathrm{~s}^{-1}$, it was estimated that in terms of the concentrations of AA used in experiments, the ratio of the quantity of SCIs reacted with 2-butanol to the quantity of SCIs reacted with AA ranged from 0.06 to 1.25 , and this ratio might be higher in exo-DB oxidation because of the formation of $\mathrm{CH}_{2} \mathrm{OO}$. This meant that part of the SCIs could react with 2-butanol, producing $\alpha$-alkoxyalkyl-hydroperoxides and contributing to the observed SOAs, especially when using low concentrations of AA and water. To figure out whether the SOA formation potentials of SCIs estimated here were higher than those under the situation without 2-butanol, the experiments with cyclohexane as the $\mathrm{OH}$ scavenger were carried out, and the details are described in the Supplement. It was found that with the use of cyclohexane, SCI reactions still accounted for more than $60 \%$ in SOA formation and, according to the fitting results, the SOA formation potentials of SCIs were even a bit larger than those with the use of 2-butanol and their deviations were within $12 \%$. This phenomenon was speculated to be due to the higher concentration of $\mathrm{RO}_{2}$ radicals when using cyclohexane, promoting the reactions of SCIs with $\mathrm{RO}_{2}$. To further determine the impact of 2-butanol, we also conducted experiments with the concentration of 2-butanol as about $150 \mathrm{ppmv}$, which was half of the previous concentration of 2-butanol used in experiments and was estimated to be sufficient for scavenging more than $99 \%$ of $\mathrm{OH}$ radicals. It was observed that the amount of SOA formation was not impacted by the concentration of 2butanol, and the SOA formation potentials of SCIs under a lower concentration of 2-butanol were similar with those under a higher concentration of 2-butanol. Based on the results elaborated above, we confirmed that the effect of 2-butanol on the results was limited. Besides, products formed from SCIs' reaction with AA and water might further react with SCIs and impact aerosol formation (Chen et al., 2019). However, due to the short lifetime and low concentration of SCIs in system, the concentration of SCIs was a limiting factor in bimolecular reactions of SCIs with other products. The major role of SCI scavengers was consuming SCIs in the reaction system, and the effect of products formed from SCI scavengers on SCI reactions was not expected to be important.

\subsubsection{Reasons for different performances of SCIs under different RH levels}

A turning point of RH in the SOA formation potential of SCIs was observed, which could not be explained by gas-phase reaction mechanisms. The different performances of SCIs in low- and high-humidity conditions were speculated to be due to the impact of the change in the aerosol phase state on some chemical reactions. Some studies have reported that the transition for the state of monoterpene-derived SOAs was $65 \%$ RH-90 \% RH (Bateman et al., 2015, 2016), while the transition for SOA chemical reactivity is $35 \% \mathrm{RH}-45 \% \mathrm{RH}$ (Li et al., 2015). A similar turning point of RH in the formation of particulate dimers in monoterpene ozonolysis was reported by Kristensen et al. (2014), who observed that the concentration of dimers in particles above $50 \% \mathrm{RH}$ was double that observed below $50 \% \mathrm{RH}$. In this study, with the addition of AA the acidity of aerosols changed, and some reactions that happened in the bulk phase were influenced, especially under high-humidity conditions. In view of this, the effect of SOA acidity on particle-phase reactions was considered. Zhao et al. (2018) investigated the aqueous-phase hydrolysis of $\alpha$-acyloxyalkyl-hydroperoxides, which were produced from reactions of SCIs and organic acids. It was found that 

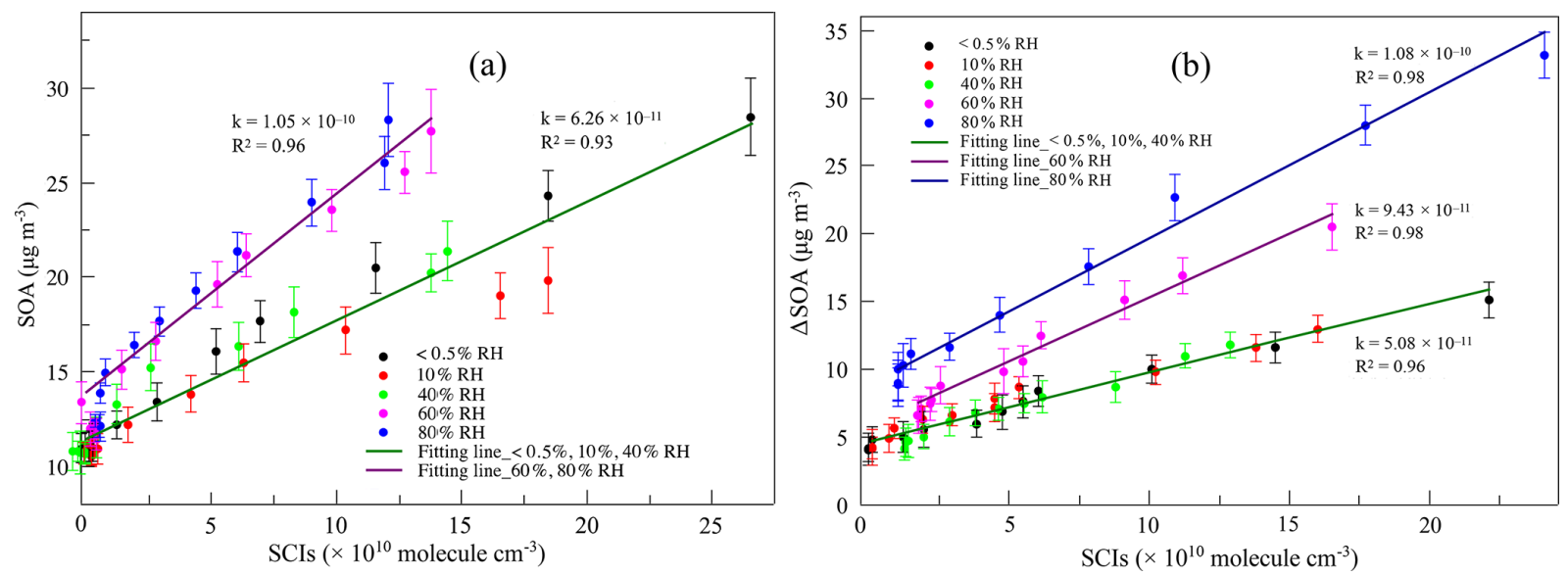

Figure 6. (a) The dependence of SOA mass concentration (SOA) on the quantity of SCIs at different relative humidity (RH) levels in the first-generation oxidation. (b) The dependence of the SOA mass concentration increment $(\triangle \mathrm{SOA})$ on the quantity of SCIs at different relative humidity (RH) levels in the second-generation oxidation.

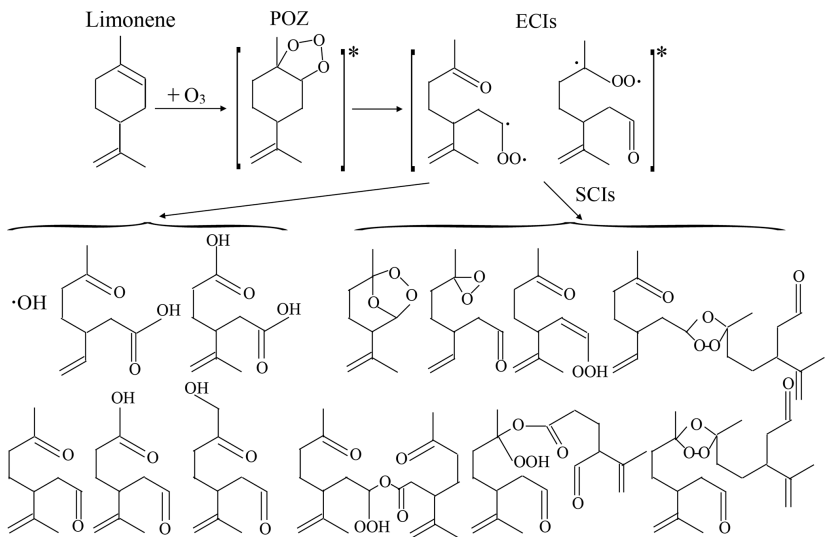

Figure 7. Reaction scheme of limonene ozonolysis.

$\alpha$-acyloxyalkyl-hydroperoxides decomposed promptly when the $\mathrm{pH}$ was larger than 5 in the aqueous phase. The aqueous decomposition of $\alpha$-hydroxyalkyl-hydroperoxides was also reported to be accelerated by acids, and the rate coefficients of decay increased with decreasing $\mathrm{pH}$ (Qiu et al., 2020a). These studies implied that acids, acting as catalysts, promoted the decomposition processes of some compounds in liquid particles and might reduce the quantity of SOAs. However, the effect of acidity on bulk-phase reactions was found to be complicated, and Iinuma et al. (2004) reported that acidity promoted the formation of large molecules in particles. Some reactions, which produced peroxyacetals, esters, aldols, etc., and contributed to SOA formation, could be catalyzed by acids and $\mathrm{H}^{+}$in the aqueous phase (Ziemann and Atkinson, 2012), while the rate coefficients of these reactions with varying $\mathrm{pH}$ were not clear. Actually, we could not evaluate the effect of acidity on the formation of SOA accurately because the acidity of aerosols might impact a series of reactions, and the mechanisms and rates of these reactions at different $\mathrm{pH}$ levels were vague. It was noted that Chen et al. (2008) found that in the aqueous-phase ozonolysis of methacrolein and methyl vinyl ketone, the yields of products were almost independent of $\mathrm{pH}$, and Zhang et al. (2009) also observed this phenomenon in the ozonolysis of $\alpha$-pinene and $\beta$-pinene in the aqueous phase. Thus the effect of the particle acidity on the results might also be limited here, and the accurate estimates of this issue still need further research.

Heterogeneous reactions on aqueous aerosols impacted the formation of SOA (Knote et al., 2014; Woo et al., 2013), and here two reaction pathways were proposed. Liquid surfaces have been proven to confine SCIs to a specific orientation, which helps to maintain the stability of SCIs and provide more opportunities for SCIs to react with other species (Qiu et al., 2018a; Zhong et al., 2017). Previous studies have reported that SCIs could react with a series of compounds at air-water interfaces (Heine et al., 2018; Kumar et al., 2017; Kumar and Francisco, 2019; Qiu et al., 2018b; Xiao et al., 2018), and some low-volatility products have been observed (Enami and Colussi, 2017b, c). Under high-humidity conditions, the heterogeneous reactions of SCIs might exist with other reaction pathways of SCIs and improve the SOA formation potential of SCIs. On the other hand, a significant amount of $\mathrm{H}_{2} \mathrm{O}_{2}$ formed from SCIs' reaction with water was observed in ozonolysis under high-humidity conditions (Chen et al., 2016; Jiang et al., 2013), and water was reported to accelerate the decomposition of $\alpha$-acyloxyalkylhydroperoxides and $\alpha$-hydroxyalkyl-hydroperoxides in the aqueous phase, resulting in the formation of $\mathrm{H}_{2} \mathrm{O}_{2}$ (Qiu et al., 2019, 2020b; Zhao et al., 2018). $\mathrm{H}_{2} \mathrm{O}_{2}$ was reported to play an important role in the nonradical oxidation of carbonyls in the aqueous phase (Galloway et al., 2011; Herrmann et al., 2015), producing hydroxyhydroperoxides and promoting SOA formation (Zhao et al., 2012, 2013). The $\mathrm{H}_{2} \mathrm{O}_{2}$ oxidation of carbonyls was speculated to mainly oc- 
cur in the surface liquid layer of aerosols, resulting in the generation of organic peroxides and high-molecular-weight oligomers (Sui et al., 2017; Zhang et al., 2019). The impact of $\mathrm{H}_{2} \mathrm{O}_{2}$ reactions at air-liquid interfaces might be another reason for the performances of SCIs in SOA formation under high-humidity conditions. The inhibitory effect of water on aerosol formation in monoterpene ozonolysis was also reported by Li et al. (2019), yet they found that the formation of $\mathrm{RO}_{2}$-derived highly oxidized molecules (HOMs) was not influenced by RH, and the reason was expected to be the SCI-derived HOMs. The main expectation of this study was to quantify the role of SCIs in SOA formation, and a limitation was the lack of measurement of aerosol composition. In the ozonolysis system the detection of products formed from SCI reactions was complicated because SCIs could react with multiple products formed from ozonolysis, and the definite reason for different SOA formation potentials of SCIs in lowand high-humidity conditions perhaps needed more composition measurements.

\subsection{The contribution of limonene-derived SCIs to SOAs in the atmosphere}

Due to the bimolecular reactions of SCIs, SOA formation from limonene ozonolysis could be influenced by other species in the atmosphere, and to evaluate the contribution of limonene ozonolysis to SOAs explicitly it is necessary to estimate the contribution of SCIs to SOAs. Here three situations - forest, urban areas, and indoor areas - were analyzed at different $\mathrm{RH}$ levels, and the concentrations of reactants are discussed below. The concentration of limonene in tropical rainforest was reported to be about $0.18 \mathrm{ppbv}$, and in urban areas 0.15 ppbv was taken as an example (Chen et al., 2010; Jia et al., 2008; Yáñez-Serrano et al., 2018). In indoor areas, some studies have observed a high indoor limonene concentration exceeding $80 \mathrm{ppbv}$ (Brown and Sim, 1994; Li et al., 2002), while a typical indoor concentration of limonene was considered to be 2 ppbv (Mandin et al., 2017; Weschler and Carslaw, 2018). The concentrations of $\mathrm{O}_{3}$ in forest and urban areas were taken as 45 ppbv (Lelieveld et al., 2008; Williams et al., 2016). Weschler (2000) claimed that the $\mathrm{O}_{3}$ concentration in indoor environments was $20 \%-70 \%$ of the outdoor concentration, and $20 \mathrm{ppbv}$ of $\mathrm{O}_{3}$ was taken as a typical indoor concentration (Weschler, 2000; Weschler and Carslaw, 2018). The concentrations of some other compounds that could impact $\mathrm{SCI}$ reactions, such as $\mathrm{SO}_{2}$ and $\mathrm{NO}_{2}$, are shown in Table S4.

To estimate the contribution of limonene-derived SCIs to SOAs in the atmosphere, the concentration of SCIs needed to be calculated, and the steady-state approximation was applied as in Eq. (4) (Percival et al., 2013):

$$
\begin{aligned}
& {[\mathrm{SCI}]_{\mathrm{Ss}}=} \\
& \frac{k_{\mathrm{ozo}} \cdot\left[\mathrm{O}_{3}\right] \cdot[\text { limonene }] \cdot Y_{\mathrm{SCI}}}{k_{\left(\mathrm{SCI}+\mathrm{H}_{2} \mathrm{O}\right)} \cdot\left[\mathrm{H}_{2} \mathrm{O}\right]+k_{\left(\mathrm{SCI}+\mathrm{SO}_{2}\right)} \cdot\left[\mathrm{SO}_{2}\right]+k_{\left(\mathrm{SCI}+\mathrm{NO}_{2}\right)} \cdot\left[\mathrm{NO}_{2}\right]+k_{(\text {other })}},
\end{aligned}
$$

where $[\mathrm{SCI}]_{\mathrm{ss}}\left(\right.$ molec. $\left.\mathrm{cm}^{-3}\right)$ is the steady-state concentration of SCIs; $k_{\text {ozo }}\left(\mathrm{cm}^{3}\right.$ molec. $\left.{ }^{-1} \mathrm{~s}^{-1}\right)$ is the rate constant of the limonene reaction with $\mathrm{O}_{3} ;\left[\mathrm{O}_{3}\right]\left(\right.$ molec. $\left.\mathrm{cm}^{-3}\right)$ is the concentration of $\mathrm{O}_{3}$; [limonene] $\left(\right.$ molec. $\left.\mathrm{cm}^{-3}\right)$ is the concentration of limonene; $Y_{\mathrm{SCI}}$ is the molar yield of SCIs; $k_{\left(\mathrm{SCI}+\mathrm{H}_{2} \mathrm{O}\right)}\left(\mathrm{cm}^{3}\right.$ molec. $\left.{ }^{-1} \mathrm{~s}^{-1}\right)$ is the rate constant of SCIs' reaction with $\mathrm{H}_{2} \mathrm{O}$, which is $5 \times 10^{-16} \mathrm{~cm}^{3}$ molec. ${ }^{-1} \mathrm{~s}^{-1}$ as derived in this study; $\left[\mathrm{H}_{2} \mathrm{O}\right]\left(\right.$ molec. $\left.\mathrm{cm}^{-3}\right)$ is the concentration of $\mathrm{H}_{2} \mathrm{O} ; k_{(\mathrm{SCI}+\mathrm{SO} 2)}\left(\mathrm{cm}^{3}\right.$ molec. $\left.{ }^{-1} \mathrm{~s}^{-1}\right)$ is the rate constant of SCIs' reaction with $\mathrm{SO}_{2}$, which is assumed to be $1 \times 10^{-11} \mathrm{~cm}^{3}$ molec. $^{-1} \mathrm{~s}^{-1}$ (Lin and Chao, 2017); $\left[\mathrm{SO}_{2}\right]\left(\right.$ molec. $\left.\mathrm{cm}^{-3}\right)$ is the concentration of $\mathrm{SO}_{2} ; k_{(\mathrm{SCI}+\mathrm{NO} 2)}$ $\left(\mathrm{cm}^{3}\right.$ molec. $\left.{ }^{-1} \mathrm{~s}^{-1}\right)$ is the rate constant of SCIs' reaction with $\mathrm{NO}_{2}$, which is assumed as $1 \times 10^{-12} \mathrm{~cm}^{3}$ molec. ${ }^{-1} \mathrm{~s}^{-1}$ ( Lin and Chao, 2017); $\left[\mathrm{NO}_{2}\right]\left(\right.$ molec. $\left.\mathrm{cm}^{-3}\right)$ is the concentration of $\mathrm{NO}_{2}$; and $k_{\text {(other) }}\left(\mathrm{s}^{-1}\right)$ accounts for the sum of SCIs' isomerization and reaction with other VOCs, and the value is also derived in the experiments. The concentrations of $\mathrm{SCI}_{\mathrm{I}}$ and $\mathrm{SCI}_{\mathrm{II}}$ were calculated separately, and the ozonolysis of both endo-DBs and exo-DBs was considered. The concentration of SCIs was enormously affected by changing $\mathrm{RH}$, and with the increase in $\mathrm{RH}$ to $100 \%$ the SCI concentration decreased to the minimum. In forest, the range of SCI concentration varies $2.65 \times 10^{3}-$ $1.01 \times 10^{4}$ molec. $\mathrm{cm}^{-3}$, and in urban and indoor areas the ranges of variation are $2.15 \times 10^{3}-7.86 \times 10^{3}$ molec. $\mathrm{cm}^{-3}$ and $1.28 \times 10^{4}-4.65 \times 10^{4}$ molec. $\mathrm{cm}^{-3}$, respectively. In forest, the typical RH is higher than $60 \%$, and for urban and indoor areas, they are usually under low-humidity conditions (Carslaw, 2017; Vereecken et al., 2012). According to the SOA formation potential of SCIs, it is estimated that the typical contribution of limonene-derived SCIs to SOA formation is $(8.21 \pm 0.15) \times 10^{-2} \mu \mathrm{g} \mathrm{m}^{-3} \mathrm{~h}^{-1}$ in forest, $(4.26 \pm 0.46) \times 10^{-2} \mu \mathrm{g} \mathrm{m}^{-3} \mathrm{~h}^{-1}$ in urban areas, and $(2.52 \pm 0.28) \times 10^{-1} \mu \mathrm{g} \mathrm{m}^{-3} \mathrm{~h}^{-1}$ in indoor areas. As the concentrations of reactants used in experiments were higher than those in the real atmosphere, we analyze the effect of the concentrations on the results in the Supplement and confirm the feasibility of extrapolating the results in the laboratory to the ambient air.

\section{Conclusions}

This study investigated SOA formation of both the first- and second-generation oxidations in limonene ozonolysis at different RH levels, with the aim of extending our understanding of SCI performances in SOA formation. The reaction pathways of SCIs in the ozonolysis system were complex, and to figure out the role of SCIs in SOA formation, the quantity of SCIs was regulated to observe their influence on SOA formation and estimate the fraction of SCIs participating in SOA formation. Results showed that SOA formation from ECI isomerization was scarcely influenced by water, while SCI reactions helped to explain the uncertainty in the wa- 
ter effect on SOA formation in ozonolysis. Although part of the SCIs was consumed by water, the contribution of SCIs to SOA under high-humidity conditions still resembled that obtained under dry conditions. The significant positive correlation between SOA formation and SCIs implied that the SOA formation potential of SCIs could be maintained stably without obvious impact from the oxidation degree. The SOA formation potential of SCIs under high-humidity conditions was nearly double that under dry and low-humidity conditions. SOA formation from limonene ozonolysis was impacted by changing RH due to SCI reactions, and the contribution of SCIs to SOA needed to be considered in models even under high RH levels. As an important monoterpene in the atmosphere, limonene has similarities in chemical structures with its isomers, $\alpha$-pinene and $\beta$-pinene. Limonene has a similar endo-DB to $\alpha$-pinene and a similar exo-DB to $\beta$ pinene. The role of limonene-derived SCIs in SOA formation observed here might be compared with $\alpha$-pinene-derived and $\beta$-pinene-derived SCIs and helped to explain the effect of water on SOA formation in ozonolysis, which was a disputable issue. In previous studies, the water effect on SOA formation in $\alpha$-pinene ozonolysis was reported to be not uniform (Bonn et al., 2002; Jonsson et al., 2008; Li et al., 2019). In $\beta$-pinene ozonolysis, water was found to reduce aerosol formation under low-humidity conditions (Bonn et al., 2002; Emanuelsson et al., 2013). In this study, the performances of SCIs formed from endo-DB and exo-DB ozonolysis of limonene showed consistency. In both of the endo-DB and the exo-DB oxidations, water was found to be an uncertainty in SCI reactions and producing aerosols. Gas-phase water consumed part of the SCIs and hindered SOA formation, while condensed-phase water improved the contribution of SCI reactions to SOAs through changing the phase of aerosols and heterogeneous reactions. This study provides new insights into the role of SCIs in SOA formation from a quantitative point of view, and further studies on the highmolecular-weight products formed from SCIs are required to comprehend the role of SCIs played in the atmosphere.

Data availability. The data are accessible by contacting the corresponding author (zmchen@pku.edu.cn).

Supplement. The supplement related to this article is available online at: https://doi.org/10.5194/acp-21-813-2021-supplement.

Author contributions. YG designed the study, carried out the experiments, and wrote the paper. ZC helped interpret the results and modified the paper.

Competing interests. The authors declare that they have no conflict of interest.
Acknowledgements. We gratefully thank the editor and two anonymous reviewers for their constructive suggestions that helped us to improve the article.

Financial support. This research has been supported by the National Key Research and Development Program of China (grant no. 2016YFC0202704) and the National Natural Science Foundation of China (grant no. 21477002).

Review statement. This paper was edited by Nga Lee $\mathrm{Ng}$ and reviewed by two anonymous referees.

\section{References}

Ahmad, W., Coeur, C., Cuisset, A., Coddeville, P., and Tomas, A.: Effects of scavengers of Criegee intermediates and $\mathrm{OH}$ radicals on the formation of secondary organic aerosol in the ozonolysis of limonene, J. Aerosol Sci., 110, 70-83, https://doi.org/10.1016/j.jaerosci.2017.05.010, 2017.

Andersson-Sköld, Y. and Simpson, D.: Secondary organic aerosol formation in northern Europe: A model study, J. Geophys. Res., 106, 7357-7374, https://doi.org/10.1029/2000JD900656, 2001.

Anglada, J. M., Aplincourt, P., Bofill, J. M., and Cremer, D.: Atmospheric formation of $\mathrm{OH}$ radicals and $\mathrm{H}_{2} \mathrm{O}_{2}$ from alkene ozonolysis under humid conditions, Chem. Phys. Chem., 3, 215-221, https://doi.org/10.1002/1439-7641(20020215)3:2<215::AIDCPHC215>3.0.CO;2-3, 2002.

Aplincourt, P. and Ruiz-Loìpez, M. F.: Theoretical study of formic acid anhydride formation from carbonyl oxide in the atmosphere, J. Phys. Chem. A, 104, 380-388, https://doi.org/10.1021/jp9928208, 2000.

Aroeira, G. J. R., Abbott, A. S., Elliott, S. N., Turney, J. M., and Schaefer, H. F.: The addition of methanol to Criegee intermediates, Phys. Chem. Chem. Phys., 21, 17760-17771, https://doi.org/10.1039/C9CP03480C, 2019.

Atkinson, R.: Gas-phase tropospheric chemistry of organic compounds: A review, Atmos. Environ. Part A, 24, 1-41, https://doi.org/10.1016/j.atmosenv.2007.10.068, 1990.

Atkinson, R. and Arey, J.: Atmospheric degradation of volatile organic compounds, Chem. Rev., 103, 4605-4638, https://doi.org/10.1021/cr0206420, 2003.

Bateman, A. P., Bertram, A. K., and Martin, S. T.: Hygroscopic influence on the semisolid-to-liquid transition of secondary organic materials, J. Phys. Chem. A, 119, 4386-4395, https://doi.org/10.1021/jp508521c, 2015.

Bateman, A. P., Gong, Z. H., Liu, P. F., Sato, B., Cirino, G., Zhang, Y., Artaxo, P., Bertram, A. K., Manzi, A. O., Rizzo, L. V., Souza, R. A. F., Zaveri, R. A., and Martin, S. T.: Sub-micrometre particulate matter is primarily in liquid form over Amazon rainforest, Nat. Geosci,. 6, 34-37, https://doi.org/10.1038/ngeo2599, 2016.

Berndt, T., Böge, O., and Stratmann, F.: Gas-phase ozonolysis of $\alpha$-pinene: gaseous products and particle formation, Atmos. Environ., 37, 3933-3945, https://doi.org/10.1016/S13522310(03)00501-6, 2003.

Berndt, T., Kaethner, R., Voigtländer, J., Stratmann, F., Pfeifle, M., Reichle, P., Sipilä, M., Kulmala, M., and Olzmann, M.: Kinetics 
of the unimolecular reaction of $\mathrm{CH}_{2} \mathrm{OO}$ and the bimolecular reactions with the water monomer, acetaldehyde and acetone under atmospheric conditions, Phys. Chem. Chem. Phys., 17, 1986219873, https://doi.org/10.1039/C5CP02224J, 2015.

Bonn, B., Schuster, G., and Moortgat, G. K.: Influence of water vapor on the process of new particle formation during monoterpene ozonolysis, J. Phys. Chem. A, 106, 2869-2881, https://doi.org/10.1021/jp012713p, 2002.

Bracco, L. L. B., Tucceri, M. E., Escalona, A., Diaz-de-Mera, Y., Aranda, A., Rodriguez, A. M., and Rodriguez, D.: New particle formation from the reactions of ozone with indene and styrene, Phys. Chem. Chem. Phys., 21, 11214-11225, https://doi.org/10.1039/C9CP00912D, 2019.

Brown, S. K. and Sim, M. R.: Concentrations of volatile organic compounds in indoor air - a review, Indoor Air, 4, 123-134, https://doi.org/10.1111/j.1600-0668.1994.t01-2-00007.x, 1994.

Brune, W. H.: The chamber wall index for gas-wall interactions in atmospheric environmental enclosures, Environ. Sci. Technol., 53, 3645-3652, https://doi.org/10.1021/acs.est.8b06260, 2019.

Cabezas, C. and Endo, Y.: Observation of hydroperoxyethyl formate from the reaction between the methyl Criegee intermediate and formic acid, Phys. Chem. Chem. Phys., 22, 446, https://doi.org/10.1039/C9CP05030B, 2020.

Carslaw, N.: A new detailed chemical model for indoor air pollution, Atmos. Environ., 41, 1164-1179, https://doi.org/10.1016/j.atmosenv.2006.09.038, 2007.

Chang, Y. P., Chang, H. H., and Lin, J. J. M.: Kinetics of the simplest Criegee intermediate reaction with ozone studied using a mid-infrared quantum cascade laser spectrometer, Phys. Chem. Chem. Phys., 20, 97-102, https://doi.org/10.1039/C7CP06653H, 2018.

Chen, H. W., Ho, K. F., Lee, S. C., and Nichol, J. E.: Biogenic volatile organic compounds (BVOC) in ambient air over Hong Kong: analytical methodology and field measurement, Intern. J. Environ. Anal. Chem., 90, 988-999, https://doi.org/10.1080/03067310903108360, 2010.

Chen, L., Wang, W. L., Wang, W. N., Liu, Y. L., Liu, F. Y., Liu, N., and Wang, B. Z.: Water-catalyzed decomposition of the simplest Criegee intermediate $\mathrm{CH}_{2} \mathrm{OO}$, Theor. Chem. Acc., 135, 131, https://doi.org/10.1007/s00214-016-1894-9, 2016.

Chen, L., Huang, Y., Xue, Y., Shen, Z., Cao, J., and Wang, W.: Mechanistic and kinetics investigations of oligomer formation from Criegee intermediate reactions with hydroxyalkyl hydroperoxides, Atmos. Chem. Phys., 19, 4075-4091, https://doi.org/10.5194/acp-19-4075-2019, 2019.

Chen, Z. M., Wang, H. L., Zhu, L. H., Wang, C. X., Jie, C. Y., and Hua, W.: Aqueous-phase ozonolysis of methacrolein and methyl vinyl ketone: a potentially important source of atmospheric aqueous oxidants, Atmos. Chem. Phys., 8, 2255-2265, https://doi.org/10.5194/acp-8-2255-2008, 2008.

Chhantyal-Pun, R., Rotavera, B., McGillen, M, R., Khan, M. A. H., Eskola, A. J., Caravan, R. L., Blacher, L., Tew, D. P., Osborn, D. L., Percival, C. J., Taatjes, C. A., Shallcross, D. E., and Orr-Ewing, A. J.: Criegee intermediate reactions with carboxylic acids: a potential source of secondary organic aerosol in the atmosphere, ACS Earth Space Chem., 2, 833-842, https://doi.org/10.1021/acsearthspacechem.8b00069, 2018.
Chuang, W. K. and Donahue, N. M.: Dynamic consideration of smog chamber experiments, Atmos. Chem. Phys., 17, 1001910036, https://doi.org/10.5194/acp-17-10019-2017, 2017.

Criegee, R. and Wenner, G.: Die Ozonisierung des 9,10-Oklins, Liebigs Ann. Chem., 564, 9-15, https://doi.org/10.1002/jlac.19495640103, 1949.

Drozd, G. T. and Donahue, N. M.: Pressure dependence of stabilized Criegee intermediate formation from a sequence of alkenes, J. Phys. Chem., 115, 4381-4387, https://doi.org/10.1021/jp2001089, 2011.

Elsamra, R. M., Jalan, A., Buras, Z. J., Middaugh, J. E., and Green, W. H.: Temperature- and pressure-dependent kinetics of $\mathrm{CH}_{2} \mathrm{OO}+\mathrm{CH}_{3} \mathrm{COCH}_{3}$ and $\mathrm{CH}_{2} \mathrm{OO}+\mathrm{CH}_{3} \mathrm{CHO}$ : direct measurements and theoretical analysis, Int. J. Chem. Kinet., 48, 474488, https://doi.org/10.1002/kin.21007, 2016.

Emanuelsson, E. U., Watne, A. K., Lutz, A., Ljungström, E., and Hallquist, M.: Influence of humidity, temperature, and radicals on the formation and thermal properties of secondary organic aerosol (SOA) from ozonolysis of $\beta$ pinene, J. Phys. Chem. A, 117, 10346-10358, https://doi.org/10.1021/jp4010218, 2013.

Enami, S. and Colussi, A. J.: Criegee chemistry on aqueous organic surfaces, J. Phys. Chem. Lett., 8, 1615-1623, https://doi.org/10.1021/acs.jpclett.7b00434, 2017a.

Enami, S. and Colussi, A. J.: Reactions of Criegee intermediates with alcohols at air-aqueous interfaces, J. Phys. Chem. A, 121, 5175-5182, https://doi.org/10.1021/acs.jpca.7b04272, 2017b.

Enami, S. and Colussi, A. J.: Efficient scavenging of Criegee intermediates on water by surface-active cispinonic acid, Phys. Chem. Chem. Phys., 19, 17044-17051, https://doi.org/10.1039/C7CP03869K, 2017c.

Enami, S., Hoffmann, M. R., and Colussi, A. J.: Prompt formation of organic acids in pulse ozonation of terpenes on aqueous surfaces, J. Phys. Chem. Lett., 1, 2374-2379, https://doi.org/10.1021/jz100847a, 2010.

Ezell, M. J., Johnson, S. N., Yu, Y., Perraud, V., Bruns, E. A., Alexander, M. L., Zelenyuk, A., Dabdub, D., and Finlayson-Pitts, B. J.: A new aerosol flow system for photochemical and thermal studies of tropospheric aerosols, Aerosol Sci. Technol., 44, 329338, https://doi.org/10.1080/02786821003639700, 2010.

Faust, J. A., Wong, J. P. S., Lee, A. K. Y., and Abbatt, J. P. D.: Role of aerosol liquid water in secondary organic aerosol formation from volatile organic compounds, Environ. Sci. Technol., 51, 1405-1413, https://doi.org/10.1021/acs.est.6b04700, 2017.

Fick, J., Pommer, L., Nilsson, C., and Andersson, B.: Effect of OH radicals, relative humidity, and time on the composition of the products formed in the ozonolysis of $\alpha$-pinene, Atmos. Environ., 37, 4087-4096, https://doi.org/10.1016/S1352-2310(03)005223, 2003.

Galloway, M. M., Loza, C. L., Chhabra, P. S., Chan, A. W. H., Yee, L. D., Seinfeld, J. H., and Keutsch, F. N.: Analysis of photochemical and dark glyoxal uptake: implications for SOA formation, Geophys. Res. Lett., 38, L17811, https://doi.org/10.1029/2011GL048514, 2011.

Gong, Y., Chen, Z., and Li, H.: The oxidation regime and SOA composition in limonene ozonolysis: roles of different double bonds, radicals, and water, Atmos. Chem. Phys., 18, 1510515123, https://doi.org/10.5194/acp-18-15105-2018, 2018.

Hasson, A. S., Ho, A. W., Kuwata, K. T., and Paulson, S. E.: Production of stabilized Criegee intermediates and perox- 
ides in the gas phase ozonolysis of alkenes: 2. Asymmetric and biogenic alkenes, J. Geophys. Res., 106, 34143-34153, https://doi.org/10.1029/2001JD000598, 2001.

Hasson, A. S., Chung, M. Y., Kuwata, K. T., Converse, A. D., Krohn, D., and Paulson, S. E.: Reaction of Criegee intermediates with water vapors an additional source of $\mathrm{OH}$ radicals in alkene ozonolysis, J. Phys. Chem. A, 107, 6176-6182, https://doi.org/10.1021/jp0346007, 2003.

Heine, N., Arata, C., Goldstein, A. H., Houle, F. A., and Wilson, K. R.: Multiphase mechanism for the production of sulfuric acid from $\mathrm{SO}_{2}$ by Criegee intermediates formed during the heterogeneous reaction of ozone with squalene, J. Phys. Chem. Lett., 9, 3504-3510, https://doi.org/10.1021/acs.jpclett.8b01171, 2018.

Herrmann, H., Schaefer, T., Tilgner, A., Styler, S. A., Weller, C., Teich, M., and Otto, T.: Tropospheric aqueousphase chemistry: kinetics, mechanisms, and its coupling to a changing gas phase, Chem. Rev., 115, 4259-4334, https://doi.org/10.1021/cr500447k, 2015.

Hua, W., Chen, Z. M., Jie, C. Y., Kondo, Y., Hofzumahaus, A., Takegawa, N., Chang, C. C., Lu, K. D., Miyazaki, Y., Kita, K., Wang, H. L., Zhang, Y. H., and Hu, M.: Atmospheric hydrogen peroxide and organic hydroperoxides during PRIDE-PRD'06, China: their concentration, formation mechanism and contribution to secondary aerosols, Atmos. Chem. Phys., 8, 6755-6773, https://doi.org/10.5194/acp-8-6755-2008, 2008.

Huang, D., Chen, Z. M., Zhao, Y., and Liang, H.: Newly observed peroxides and the water effect on the formation and removal of hydroxyalkyl hydroperoxides in the ozonolysis of isoprene, Atmos. Chem. Phys., 13, 5671-5683, https://doi.org/10.5194/acp13-5671-2013, 2013.

Huang, H. L., Chao, W., and Lin, J. J. M.: Kinetics of a Criegee intermediate that would survive high humidity and may oxidize atmospheric $\mathrm{SO}_{2}$, P. Natl. Acad. Sci., 112, 10857-10862, https://doi.org/10.1073/pnas.1513149112, 2015.

Iinuma, Y., Böge, O., Gnauk, T., and Herrmann, H.: Aerosolchamber study of the $\alpha$-pinene $/ \mathrm{O}_{3}$ reaction: influence of particle acidity on aerosol yields and products, Atmos. Environ., 38, 761-773, https://doi.org/10.1016/j.atmosenv.2003.10.015, 2004.

Jenkin, M. E.: Modelling the formation and composition of secondary organic aerosol from $\alpha$ - and $\beta$-pinene ozonolysis using MCM v3, Atmos. Chem. Phys., 4, 1741-1757, https://doi.org/10.5194/acp-4-1741-2004, 2004.

Jia, C. R., Batterman, S., and Godwin, C.: VOCs in industrial, urban and suburban neighborhoods, Part 1: Indoor and outdoor concentrations, variation, and risk drivers, Atmos. Environ., 42, 20832100, https://doi.org/10.1016/j.atmosenv.2007.11.055, 2008.

Jiang, L., Lan, R., Xu, Y. S., Zhang, W. J., and Yang, W.: Reaction of stabilized Criegee intermediates from ozonolysis of limonene with water: Ab Initio and DFT study, Int. J. Mol. Sci., 14, 57845805, https://doi.org/10.3390/ijms14035784, 2013.

Johnson, D. and Marston, G.: The gas-phase ozonolysis of unsaturated volatile organic compounds in the troposphere, Chem. Soc. Rev., 37, 699-716, https://doi.org/10.1039/b704260b, 2008.

Jonsson, A. M., Hallquist, M., and Ljungström, E.: The effect of temperature and water on secondary organic aerosol formation from ozonolysis of limonene, $\Delta^{3}$-carene and $\alpha$-pinene, Atmos. Chem. Phys., 8, 6541-6549, https://doi.org/10.5194/acp-8-65412008, 2008.
Khan, M. A. H., Percival, C. J., Caravan, R. L., Taatjes, C. A., and Shallcross, D. E.: Criegee intermediates and their impacts on the troposphere, Environ. Sci., 20, 437-453, https://doi.org/10.1039/C7EM00585G, 2018.

Khan, M. A. K., Morris, W. C., Galloway, M., Shallcross, B. M. A., Percival, C. J., and Shallcross, D. E.: An estimation of the levels of stabilized Criegee intermediates in the UK urban and rural atmosphere using the steady-state approximation and the potential effects of these intermediates on tropospheric oxidation cycles, Int. J. Chem. Kinet., 49, 611-621, https://doi.org/10.1002/kin.21101, 2017.

Kim, S., Guenther, A., Lefer, B., Flynn, J., Griffin, R., Rutter, A. P., Gong, L. W., and Cevik, B. K.: Potential role of stabilized Criegee radicals in sulfuric acid production in a high biogenic VOC environment, Environ. Sci. Technol., 49, 3383-3391, https://doi.org/10.1021/es505793t, 2015.

Kjaergaard, H. G., Kurten, T., Nielsen, L. B., Jørgensen, S., and Wennberg, P. O.: Criegee intermediates react with ozone, J. Phys. Chem. Lett., 4, 2525-2529, https://doi.org/10.1021/jz401205m, 2013.

Knote, C., Hodzic, A., Jimenez, J. L., Volkamer, R., Orlando, J. J., Baidar, S., Brioude, J., Fast, J., Gentner, D. R., Goldstein, A. H., Hayes, P. L., Knighton, W. B., Oetjen, H., Setyan, A., Stark, H., Thalman, R., Tyndall, G., Washenfelder, R., Waxman, E., and Zhang, Q.: Simulation of semi-explicit mechanisms of SOA formation from glyoxal in aerosol in a 3-D model, Atmos. Chem. Phys., 14, 6213-6239, https://doi.org/10.5194/acp14-6213-2014, 2014.

Kristensen, K., Cui, T., Zhang, H., Gold, A., Glasius, M., and Surratt, J. D.: Dimers in $\alpha$-pinene secondary organic aerosol: effect of hydroxyl radical, ozone, relative humidity and aerosol acidity, Atmos. Chem. Phys., 14, 4201-4218, https://doi.org/10.5194/acp-14-4201-2014, 2014.

Kumar, M. and Francisco, J. S.: Elucidating the molecular mechanisms of Criegee-amine chemistry in the gas phase and aqueous surface environments, Chem. Sci., 10, 743-751, https://doi.org/10.1039/C8SC03514H, 2019.

Kumar, M., Busch, D. H., Subramaniam, B., and Thompson, W. H.: Barrierless tautomerization of Criegee intermediates via acid catalysis, Phys. Chem. Chem. Phys., 16, 22968, https://doi.org/10.1039/C4CP03065F, 2014a.

Kumar, M., Busch, D. H., Subramaniam, B., and Thompson, W. H.: Role of tunable acid catalysis in decomposition of hydroxyalkyl hydroperoxides and mechanistic implications for tropospheric chemistry, J. Phys. Chem. A, 118, 9701-9711, https://doi.org/10.1021/jp505100x, 2014b.

Kumar, M., Zhong, J., Francisco, J. S., and Zeng, X. C.: Criegee intermediate-hydrogen sulfide chemistry at the air/water interface, Chem. Sci., 8, 5385-5391, https://doi.org/10.1039/C7SC01797A, 2017.

Kumar, M., Zhong, J., Zeng, X. C., and Francisco, J. S.: Reaction of Criegee intermediate with nitric acid at the air-water interface, J. Am. Chem. Soc., 140, 4913-4921, https://doi.org/10.1021/jacs.8b01191, 2018.

Lazrus, A. L., Kok, G. L., Lind, J. A., Gitlin, S. N., Heikes, B. G., and Shetter, R. E.: Automated fluorometric method for hydrogen peroxide in air, Anal. Chem., 58, 594-597, https://doi.org/10.1021/ac00294a024, 1986. 
Lee, A., Goldstein, A. H., Keywood, M. D., Gao, S., Varutbangkul, V., Bahreini, R., Ng, N. L., Flagan, R. C., and Seinfeld, J. H.: Gas-phase products and secondary aerosol yields from the ozonolysis of ten different terpenes, J. Geophys. Res., 111, D07302, https://doi.org/10.1029/2005JD006437, 2006.

Lee, S. and Kamens, R. M.: Particle nucleation from the reaction of a-pinene and $\mathrm{O}_{3}$, Atmos. Environ., 39, 6822-6832, https://doi.org/10.1016/j.atmosenv.2005.07.062, 2005.

Lelieveld, J., Butler, T. M., Crowley, J. N., Dillon, T. J., Fischer, H., Ganzeveld, L., Harder, H., Lawrence, M. G., Martinez, M., Taraborrelli, D., and Williams, J.: Atmospheric oxidation capacity sustained by a tropical forest, Nature, 452, 737-740, https://doi.org/10.1038/nature06870, 2008.

Leungsakul, S., Jaoui, M., and Kamens, R. M.: Kinetic mechanism for predicting secondary organic aerosol formation from the reaction of d-limonene with ozone, Environ. Sci. Technol., 39, 9583-9594, https://doi.org/10.1021/es0492687, 2005.

Li, H., Chen, Z., Huang, L., and Huang, D.: Organic peroxides' gasparticle partitioning and rapid heterogeneous decomposition on secondary organic aerosol, Atmos. Chem. Phys., 16, 1837-1848, https://doi.org/10.5194/acp-16-1837-2016, 2016.

Li, T. H., Turpin, B. J., Shields, H. C., and Weschler, C. J.: Indoor hydrogen peroxide derived from ozone/dlimonene reactions, Environ. Sci. Technol., 36, 3295-3302, https://doi.org/10.1021/es015842s, 2002.

Li, X., Chee, S., Hao, J., Abbatt, J. P. D., Jiang, J., and Smith, J. N.: Relative humidity effect on the formation of highly oxidized molecules and new particles during monoterpene oxidation, Atmos. Chem. Phys., 19, 1555-1570, https://doi.org/10.5194/acp19-1555-2019, 2019.

Li, Y. J., Liu, P. F., Gong, Z. H., Wang, Y., Bateman, A. P., Bergoend, C., Bertram, A. K., and Martin, S. T.: Chemical reactivity and liquid/nonliquid states of secondary organic material, Environ. Sci. Technol., 49, 13264-13274, https://doi.org/10.1021/acs.est.5b03392, 2015.

Lin, J. J. M. and Chao, W.: Structure-dependent reactivity of Criegee intermediates studied with spectroscopic methods, Chem. Soc. Rev., 46, 7483-7497, https://doi.org/10.1039/C7CS00336F, 2017.

Liu, F., Fang, Y., Kumar, M., Thompson, W. H., and Lester, M. I.: Direct observation of vinyl hydroperoxides, Phys. Chem. Chem. Phys., 17, 20490, https://doi.org/10.1039/c5cp02917a, 2015.

Long, B., Cheng, J. R., Tan, X. F., and Zhang, W. J.: Theoretical study on the detailed reaction mechanisms of carbonyl oxide with formic acid, J. Mol. Struct., 916, 159-167, https://doi.org/10.1016/j.theochem.2009.09.028, 2009.

Long, B., Bao, J. L., and Truhlar, D. G.: Unimolecular reaction of acetone oxide and its reaction with water in the atmosphere, P. Natl. Acad. Sci., 115, 6135-6140, https://doi.org/10.1073/pnas.1804453115, 2018.

Long, B., Bao, J. L., and Truhlar, D. G.: Rapid unimolecular reaction of stabilized Criegee intermediates and implications for atmospheric chemistry, Nat. Commun., 10, 2003, https://doi.org/10.1038/s41467-019-09948-7, 2019.

Ma, Y., Russell, A. T., and Marston, G.: Mechanisms for the formation of secondary organic aerosol components from the gasphase ozonolysis of $\alpha$-pinene, Phys. Chem. Chem. Phys., 10, 4294-4312, https://doi.org/10.1039/b803283a, 2008.
Mandin, C., Trantallidi, M., Cattaneo, A., Canha, N., Mihucz, V. G., Szigeti, T., Mabilia, R., Perreca, E., Spinazze, A., Fossati, S., Kluizenaar, Y. D., Cornelissen, E., Sakellaris, I., Saraga, D., Hänninen, O., Fernandes, E. D. O., Ventura, G., Wolkoff, P., Carrer, P., and Bartzis, J.: Assessment of indoor air quality in office buildings across Europe - The OFFICAIR study, Sci. Total Environ., 579, 169-178, https://doi.org/10.1016/j.scitotenv.2016.10.238, 2017.

Matsuoka, K., Sakamoto, Y., Hama, T., Kajii, Y., and Enami, S.: Reactive uptake of gaseous sesquiterpenes on aqueous surfaces, J. Phys. Chem. A, 121, 810-818, https://doi.org/10.1021/acs.jpca.6b11821, 2017.

Mauldin III, R. L., Berndt, T., Sipilä, M., Paasonen, P., Petäjä, T., Kim, S., Kurten, T., Stratmann, F., Kerminen, V. M., and Kulmala, M.: A new atmospherically relevant oxidant of sulphur dioxide, Nature, 488, 193-197, https://doi.org/10.1038/nature11278, 2012.

McGillen, M. R., Curchod, B. F. E., Chhantyal-Pun, R., Beames, J. M., Watson, N., Khan, M. A. H., McMahon, L., Shallcross, D. E., and Oee-Ewing, A. J.: Criegee intermediatealcohol reactions, a potential source of functionalized hydroperoxides in the atmosphere, ACS Earth Space Chem., 1, 664-672, https://doi.org/10.1021/acsearthspacechem.7b00108, 2017.

McVay, R. C., Cappa, C. D., and Seinfeld, J. H.: Vapor-wall deposition in chambers: theoretical considerations, Environ. Sci. Technol., 48, 10251-10258, https://doi.org/10.1021/es502170j, 2014.

McVay, R. C., Zhang, X., Aumont, B., Valorso, R., Camredon, M., La, Y. S., Wennberg, P. O., and Seinfeld, J. H.: SOA formation from the photooxidation of $\alpha$-pinene: systematic exploration of the simulation of chamber data, Atmos. Chem. Phys., 16, 27852802, https://doi.org/10.5194/acp-16-2785-2016, 2016.

Mutzel, A., Rodigast, M., Iinuma, Y., Böge, O., and Herrmann, H.: Monoterpene SOA - Contribution of firstgeneration oxidation products to formation and chemical composition, Atmos. Environ., 130, 136-144, https://doi.org/10.1016/j.atmosenv.2015.10.080, 2016.

Nah, T., McVay, R. C., Zhang, X., Boyd, C. M., Seinfeld, J. H., and $\mathrm{Ng}, \mathrm{N}$. L.: Influence of seed aerosol surface area and oxidation rate on vapor wall deposition and SOA mass yields: a case study with $\alpha$-pinene ozonolysis, Atmos. Chem. Phys., 16, 9361-9379, https://doi.org/10.5194/acp-16-9361-2016, 2016.

Nah, T., McVay, R. C., Pierce, J. R., Seinfeld, J. H., and Ng, N. L.: Constraining uncertainties in particle-wall deposition correction during SOA formation in chamber experiments, Atmos. Chem. Phys., 17, 2297-2310, https://doi.org/10.5194/acp17-2297-2017, 2017.

Newland, M. J., Rickard, A. R., Sherwen, T., Evans, M. J., Vereecken, L., Muñoz, A., Ródenas, M., and Bloss, W. J.: The atmospheric impacts of monoterpene ozonolysis on global stabilised Criegee intermediate budgets and $\mathrm{SO}_{2}$ oxidation: experiment, theory and modelling, Atmos. Chem. Phys., 18, 60956120, https://doi.org/10.5194/acp-18-6095-2018, 2018.

Ng, N. L., Kroll, J. H., Keywood, M. D., Bahreini, R., Varutbangkul, V., Flagan, R. C., Seinfeld, J. H., Lee, A., and Goldstein, A. H.: Contribution of first- versus second-generation products to secondary organic aerosols formed in the oxidation of biogenic hydrocarbons, Environ. Sci. Technol., 40, 2283-2297, https://doi.org/10.1021/es052269u, 2006. 
Osborn, D. L. and Taatjes, C. A.: The physical chemistry of Criegee intermediates in the gas phase, Int. Rev. Phys. Chem., 34, 309360, https://doi.org/10.1080/0144235X.2015.1055676, 2015.

Palm, B. B., de Sá, S. S., Day, D. A., Campuzano-Jost, P., Hu, W., Seco, R., Sjostedt, S. J., Park, J.-H., Guenther, A. B., Kim, S., Brito, J., Wurm, F., Artaxo, P., Thalman, R., Wang, J., Yee, L. D., Wernis, R., Isaacman-VanWertz, G., Goldstein, A. H., Liu, Y., Springston, S. R., Souza, R., Newburn, M. K., Alexander, M. L., Martin, S. T., and Jimenez, J. L.: Secondary organic aerosol formation from ambient air in an oxidation flow reactor in central Amazonia, Atmos. Chem. Phys., 18, 467-493, https://doi.org/10.5194/acp-18-467-2018, 2018.

Pathak, R. K., Salo, K., Emanuelsson, E. U., Cai, C., Lutz, A., Hallquist, A. M., and Hallquist, M.: Influence of ozone and radical chemistry on limonene organic aerosol production and thermal characteristics, Environ. Sci. Technol., 46, 11660-11669, https://doi.org/10.1021/es301750r, 2012.

Percival, C. J., Welz, O., Eskola, A. J., Savee, J. D., Osborn, D. L., Topping, D. O., Lowe, D., Utemne, S. R., Bacak, A., Figgans, G. M., Cooke, M. C., Xiao, P., Archibald, A. T., Jenkin, M. E., Derwent, R. G., Piipinen, I., Mok, D. W. K., Lee, E. P. F., Dyke, J. M., Taatjes, C. A., and Shallcross, D. E.: Regional and global impacts of Criegee intermediates on atmospheric sulphuric acid concentrations and first steps of aerosol formation, Faraday Discuss., 165, 45-73, https://doi.org/10.1039/c3fd00048f, 2013.

Qiu, J. T., Ishizuka, S., Tonokura, K., Colussi, A. J., and Enami, S.: Reactivity of monoterpene Criegee intermediates at gas-liquid interfaces, J. Phys. Chem. A, 122, 7910-7917, https://doi.org/10.1021/acs.jpca.8b06914, 2018a.

Qiu, J. T., Ishizuka, S., Tonokura, K., and Enami, S.: Reactions of Criegee intermediates with benzoic acid at the gas/liquid interface, J. Phys. Chem. A, 122, 6303-6310, https://doi.org/10.1021/acs.jpca.8b04995, 2018b.

Qiu, J. T., Ishizuka, S., Tonokura, K., Colussi, A., and Enami, S.: Water dramatically accelerates the decomposition of $\alpha$-hydroxyalkyl-hydroperoxides in aerosol particles, J. Phys. Chem. Lett., 10, 5748-5755, https://doi.org/10.1021/acs.jpclett.9b01953, 2019.

Qiu, J. T., Tonokura, K., and Enami, S.: Proton-catalyzed decomposition of $\alpha$-hydroxyalkyl-hydroperoxides in water, Environ. Sci. Technol., 54, 10561-10569, https://doi.org/10.1021/acs.est.0c03438, 2020a.

Qiu, J. T., Liang, Z. C., Tonokura, K., Colussi, A. J., and Enami, S.: Stability of monoterpene-derived $\alpha$-hydroxyalkylhydroperoxides in aqueous organic media: relevance to the fate of hydroperoxides in aerosol particle phases, Environ. Sci. Technol., 54, 3890-3899, https://doi.org/10.1021/acs.est.9b07497, 2020b.

Renbaum-Wolff, L., Grayson, J. W., Bateman, A. P., Kuwata, M., Sellier, M., Murray, B. J., Shilling, J. E., Martin, S. T., and Bertram, A. K.: Viscosity of $\alpha$-pinene secondary organic material and implications for particle growth and reactivity, P. Natl. Acad. Sci., 110, 8014-8019, https://doi.org/10.1073/pnas.1219548110, 2013.

Riipinen, I., Pierce, J. R., Yli-Juuti, T., Nieminen, T., Häkkinen, S., Ehn, M., Junninen, H., Lehtipalo, K., Petäjä, T., Slowik, J., Chang, R., Shantz, N. C., Abbatt, J., Leaitch, W. R., Kerminen, V.-M., Worsnop, D. R., Pandis, S. N., Donahue, N. M., and Kulmala, M.: Organic condensation: a vital link connecting aerosol formation to cloud condensation nuclei (CCN) concentrations, Atmos. Chem. Phys., 11, 3865-3878, https://doi.org/10.5194/acp-11-3865-2011, 2011.

Saathoff, H., Naumann, K.-H., Möhler, O., Jonsson, Å. M., Hallquist, M., Kiendler-Scharr, A., Mentel, Th. F., Tillmann, R., and Schurath, U.: Temperature dependence of yields of secondary organic aerosols from the ozonolysis of $\alpha$-pinene and limonene, Atmos. Chem. Phys., 9, 1551-1577, https://doi.org/10.5194/acp9-1551-2009, 2009.

Sakamoto, Y., Inomata, S., and Hirokawa, J.: Oligomerization reaction of the Criegee intermediate leads to secondary organic aerosol formation in ethylene ozonolysis, J. Phys. Chem. A, 117, 12912-12921, https://doi.org/10.1021/jp408672m, 2013.

Sakamoto, Y., Yajima, R., Inomata, S., and Hirokawa, J.: Water vapour effects on secondary organic aerosol formation in isoprene ozonolysis, Phys. Chem. Chem. Phys., 19, 3165-3175, https://doi.org/10.1039/C6CP04521A, 2017.

Sander, W.: Carbonyl oxides - rising stars in tropospheric chemistry, Angew. Chem. Int. Ed., 53, 362-364, https://doi.org/10.1002/anie.201305736, 2014.

Sheps, L., Scully, A. M., and Au, K.: UV absorption probing of the conformer-dependent reactivity of a Criegee intermediate $\mathrm{CH}_{3} \mathrm{CHOO}$, Phys. Chem. Chem. Phys., 16, 26701-26706, https://doi.org/10.1039/C4CP04408H, 2014.

Shiraiwa, M. and Seinfeld, J. H.: Equilibration timescale of atmospheric secondary organic aerosol partitioning, Geophys. Res. Lett., 39, L24801, https://doi.org/10.1029/2012GL054008, 2012.

Shu, Y. H. and Atkinson, R.: Rate constants for the gas phase reactions of $\mathrm{O}_{3}$ with a series of terpenes and $\mathrm{OH}$ radical formation from the $\mathrm{O}_{3}$ reactions with sesquiterpenes at 296 $\pm 2 \mathrm{~K}$, Int. J. Chem. Kinet., 26, 1193-1205, https://doi.org/10.1002/kin.550261207, 1994.

Sipilä, M., Jokinen, T., Berndt, T., Richters, S., Makkonen, R., Donahue, N. M., Mauldin III, R. L., Kurtén, T., Paasonen, P., Sarnela, N., Ehn, M., Junninen, H., Rissanen, M. P., Thornton, J., Stratmann, F., Herrmann, H., Worsnop, D. R., Kulmala, M., Kerminen, V.-M., and Petäjä, T.: Reactivity of stabilized Criegee intermediates (sCIs) from isoprene and monoterpene ozonolysis toward $\mathrm{SO}_{2}$ and organic acids, Atmos. Chem. Phys., 14, 12143 12153, https://doi.org/10.5194/acp-14-12143-2014, 2014.

Sui, X., Zhou, Y. F., Zhang, F., Chen, J. M., Zhu, Z. H., and Yu, X. Y.: Deciphering the aqueous chemistry of glyoxal oxidation with hydrogen peroxide using molecular imaging, Phys. Chem. Chem. Phys., 19, 20357-20366, https://doi.org/10.1039/C7CP02071F, 2017.

Taatjes, C. A., Meloni, G., Selby, T. M., Trevitt, A. J., Osborn, D. L., Percival, C. J., and Shallcross, D. E. J.: Direct observation of the gas-phase Criegee intermediate $\left(\mathrm{CH}_{2} \mathrm{OO}\right)$, Am. Chem. Soc., 130, 11883-11885, https://doi.org/10.1021/ja804165q, 2008.

Taatjes, C. A., Welz, O., Eskola, A. J., Savee, J. D., Scheer, A. M., Shallcross, D. E., Rotavera, B., Lee, E. P. F., Dyke, J. M., Mok, D. K. W., Osborn, D. L., and Percival, C. J.: Direct measurements of conformer-dependent reactivity of the Criegee intermediate $\mathrm{CH}_{3} \mathrm{CHOO}$, Science, 340, 177-180, https://doi.org/10.1126/science.1234689, 2013.

Taatjes, C. A., Shallcross, D. E., and Percival, C. J.: Research frontiers in the chemistry of Criegee intermediates and tropospheric ozonolysis, Phys. Chem. Chem. Phys., 16, 1704-1718, https://doi.org/10.1039/c3cp52842a, 2014. 
Taatjes, C. A.: Criegee Intermediates: What direct production and detection can teach us about reactions of carbonyl oxides, Annu. Rev. Phys. Chem., 68, 183-207, https://doi.org/10.1146/annurevphyschem-052516-050739, 2017.

Tadayon, S. V., Foreman, E. S., and Murray, C.: Kinetics of the reactions between the Criegee intermediate $\mathrm{CH}_{2} \mathrm{OO}$ and alcohols, J. Phys. Chem. A, 122, 258-268, https://doi.org/10.1021/acs.jpca.7b09773, 2018.

Tillmann, R., Hallquist, M., Jonsson, Å. M., Kiendler-Scharr, A., Saathoff, H., Iinuma, Y., and Mentel, Th. F.: Influence of relative humidity and temperature on the production of pinonaldehyde and $\mathrm{OH}$ radicals from the ozonolysis of $\alpha$-pinene, Atmos. Chem. Phys., 10, 7057-7072, https://doi.org/10.5194/acp10-7057-2010, 2010.

Tu, P. and Johnston, M. V.: Particle size dependence of biogenic secondary organic aerosol molecular composition, Atmos. Chem. Phys., 17, 7593-7603, https://doi.org/10.5194/acp17-7593-2017, 2017.

Veghte, D. P., Altaf, M. B., and Freedman, M. A.: Size dependence of the structure of organic aerosol, J. Am. Chem. Soc., 135, 16046-16049, https://doi.org/10.1021/ja408903g, 2013.

Vereecken, L., Harder, H., and Novelli, A.: The reaction of Criegee intermediates with $\mathrm{NO}, \mathrm{RO}_{2}$, and $\mathrm{SO}_{2}$, and their fate in the atmosphere, Phys. Chem. Chem. Phys., 14, 14682-14695, https://doi.org/10.1039/c2cp42300f, 2012.

Vereecken, L., Richard, A. R., Newland, M. J., and Bloss, W. J.: Theoretical study of the reactions of Criegee intermediates with ozone, alkylhydroperoxides, and carbon monoxide, Phys. Chem. Chem. Phys., 17, 23847-23858, https://doi.org/10.1039/c5cp03862f, 2015.

von Hessberg, C., von Hessberg, P., Pöschl, U., Bilde, M., Nielsen, O. J., and Moortgat, G. K.: Temperature and humidity dependence of secondary organic aerosol yield from the ozonolysis of $\beta$-pinene, Atmos. Chem. Phys., 9, 3583-3599, https://doi.org/10.5194/acp-9-3583-2009, 2009.

Warren, B., Malloy, Q. G. J., Yee, L. D., and Cocker III, D. R.: Secondary organic aerosol formation from cyclohexene ozonolysis in the presence of water vapor and dissolved salts, Atmos. Environ., 43, 1789-1795, https://doi.org/10.1016/j.atmosenv.2008.12.026, 2009.

Watson, N. A. I., Black, J. A., Stonelake, T. M., Knowles, P. J., and Beames, J. M.: An extended computational study of Criegee intermediate-alcohol reactions, J. Phys. Chem. A, 123, 218-229, https://doi.org/10.1021/acs.jpca.8b09349, 2019.

Welz, O., Savee, J. D., Osborn, D. L., Vasu, S. S., Percival, C. J., Shallcross, D. E., and Taatjes, C. A.: Direct kinetic measurements of Criegee intermediate $\left(\mathrm{CH}_{2} \mathrm{OO}\right)$ formed by reaction of $\mathrm{CH}_{2} \mathrm{I}$ with $\mathrm{O}_{2}$, Science, 335, 204-207, https://doi.org/10.1126/science.1213229, 2012.

Weschler, C. J.: Ozone in indoor environments: concentration and chemistry, Indoor Air, 10, 269-288, https://doi.org/10.1034/j.1600-0668.2000.010004269.x, 2000.

Weschler, C. J. and Carslaw, N.: Indoor chemistry, Environ. Sci. Technol., 52, 2419-2428, https://doi.org/10.1021/acs.est.7b06387, 2018.

Williams, J., Keßel, S. U., Nölscher, A. C., Yang, Y. D., Lee, Y., Yanez-Serrano, A. M., Wolff, S., Kesselemeier, J., Klüpfel, T., Lelieveld, J., and Shao, M.: Opposite OH reactivity and ozone cycles in the Amazon rainforest and megacity Beijing: Subversion of biospheric oxidant control by anthropogenic emissions, Atmos. Environ., 125, 112-118, https://doi.org/10.1016/j.atmosenv.2015.11.007, 2016.

Wilson, J., Imre, D., Beranek, J., Shrivastava, M., and Zelenyuk, A.: Evaporation kinetics of laboratory-generated secondary organic aerosols at elevated relative humidity, Environ. Sci. Technol., 49, 243-249, https://doi.org/10.1021/es505331d, 2015.

Winterhalter, R., Neeb, P., Grossmann, D., Kolloff, A., Horie, O., and Moortgat, G.: Products and mechanism of the gas phase reaction of ozone with $\beta$-pinene, J. Atmos. Chem, 35, 165-197, https://doi.org/10.1023/A:1006257800929, 2000.

Woo, J. L., Kim, D. D., Schwier, A. N., Li, R. Z., and McNeill, V. F.: Aqueous aerosol SOA formation: impact on aerosol physical properties, Faraday Discuss., 165, 357-367, https://doi.org/10.1039/C3FD00032J, 2013.

Xiao, P., Yang, J. J., Fang, W. H., and Cui, G. L.: QM/MM studies on ozonolysis of $\alpha$-humulene and Criegee reactions with acids and water at air-water/acetonitrile interfaces, Phys. Chem. Chem. Phys., 20, 16138-16150, https://doi.org/10.1039/C8CP01750F, 2018.

Yáñez-Serrano, A. M., Nölscher, A. C., Bourtsoukidis, E., Gomes Alves, E., Ganzeveld, L., Bonn, B., Wolff, S., Sa, M., Yamasoe, M., Williams, J., Andreae, M. O., and Kesselmeier, J.: Monoterpene chemical speciation in a tropical rainforest:variation with season, height, and time of dayat the Amazon Tall Tower Observatory (ATTO), Atmos. Chem. Phys., 18, 3403-3418, https://doi.org/10.5194/acp-18-3403-2018, 2018.

Yao, L., Ma, Y., Wang, L., Zheng, J., Khalizov, A., Chen, M. D., Zhou, Y. Y., Qi, L., and Cui, F. P.: Role of stabilized Criegee Intermediate in secondary organic aerosol formation from the ozonolysis of $\alpha$-cedrene, Atmos. Environ., 94, 448-457, https://doi.org/10.1016/j.atmosenv.2014.05.063, 2014.

Ye, J., Abbatt, J. P. D., and Chan, A. W. H.: Novel pathway of $\mathrm{SO}_{2}$ oxidation in the atmosphere: reactions with monoterpene ozonolysis intermediates and secondary organic aerosol, Atmos. Chem. Phys., 18, 5549-5565, https://doi.org/10.5194/acp18-5549-2018, 2018.

Ye, Q., Robinson, E. S., Ding, X., Ye, P. L., Sullivan, R. C., and Donahue, N. M.: Mixing of secondary organic aerosols versus relative humidity, P. Natl. Acad. Sci., 113, 12649-12654, https://doi.org/10.1073/pnas.1604536113, 2016.

Yu, K. P., Lin, C. C., Yang, S. C., and Zhao, P.: Enhancement effect of relative humidity on the formation and regional respiratory deposition of secondary organic aerosol, J. Hazard. Mater., 191, 94-102, https://doi.org/10.1016/j.jhazmat.2011.04.042, 2011.

Zhang, F., Yu, X. F., Chen, J. M., Zhu, Z. H., and Yu, X. Y.: Dark airliquid interfacial chemistry of glyoxal and hydrogen peroxide, NPJ Clim. Atmos. Sci., 2, 28, https://doi.org/10.1038/s41612019-0085-5, 2019.

Zhang, J. Y., Hartz, K. E. H., Pandis, S. N., and Donahue, N. M.: Secondary organic aerosol formation from limonene ozonolysis: homogeneous and heterogeneous influences as a function of $\mathrm{NO}_{x}$, J. Phys. Chem. A, 110, 11053-11063, https://doi.org/10.1021/jp062836f, 2006.

Zhang, X., Chen, Z. M., Wang, H. L., He, S. Z., and Huang, D. M.: An important pathway for ozonolysis of alpha-pinene and beta-pinene in aqueous phase and its atmospheric implications, Atmos. Environ., 43, 4456-4471, https://doi.org/10.1016/j.atmosenv.2009.06.028, 2009. 
Zhang, X., Cappa, C. D., Jathar, S. H., McVay, R. C., Ensberg, J. J., Kleeman, M. J., and Seinfeld, J. H.: Influence of vapor wall loss in laboratory chambers on yields of secondary organic aerosol, P. Natl. Acad. Sci. USA, 111, 5802-5807, https://doi.org/10.1073/pnas.1404727111, 2014.

Zhang, X., Schwantes, R. H., McVay, R. C., Lignell, H., Coggon, M. M., Flagan, R. C., and Seinfeld, J. H.: Vapor wall deposition in Teflon chambers, Atmos. Chem. Phys., 15, 4197-4214, https://doi.org/10.5194/acp-15-4197-2015, 2015.

Zhao, R., Lee, A. K. Y., and Abbatt, J. P. D.: Investigation of aqueous-phase photooxidation of glyoxal and methylglyoxal by aerosol chemical ionization mass spectrometry: observation of hydroxyhydroperoxide formation, J. Phys. Chem. A, 116, 62536263, https://doi.org/10.1021/jp211528d, 2012.

Zhao, R., Lee, A. K. Y., Soong, R., Simpson, A. J., and Abbatt, J. P. D.: Formation of aqueous-phase $\alpha$-hydroxyhydroperoxides $(\alpha$ HHP): potential atmospheric impacts, Atmos. Chem. Phys., 13, 5857-5872, https://doi.org/10.5194/acp-13-5857-2013, 2013.

Zhao, R., Kenseth, C. M., Huang, Y. L., Dalleska, N. F., Kuang, X. M., Chen, J. R., Paulson, S. E., and Seinfeld, J. H.: Rapid aqueous-phase hydrolysis of ester hydroperoxides arising from Criegee intermediates and organic acids, J. Phys. Chem. A, 122, 5190-5201, https://doi.org/10.1021/acs.jpca.8b02195, 2018.
Zhao, Y., Wingen, L. M., Perraud, V., Greaves, J., and FinlaysonPitts, B. J.: Role of the reaction of stabilized Criegee intermediates with peroxy radicals in particle formation and growth in air, Phys. Chem. Chem. Phys., 17, 12500-12514, https://doi.org/10.1039/c5cp01171j, 2015.

Zhong, J., Kumar, M., Zhu, C. Q., Francisco, J. S., and Zeng, X. C.: Surprising stability of larger Criegee intermediates on aqueous interfaces, Angew. Chem. Int. Ed., 56, 7740-7744, https://doi.org/10.1002/anie.201702722, 2017.

Zhong, J., Kumar, M., Francisco, J. S., and Zeng, X. C.: Insight into chemistry on cloud/aerosol water surfaces, Acc. Chem. Res., 51, 1229-1237, https://doi.org/10.1021/acs.accounts.8b00051, 2018.

Ziemann, P. J. and Atkinson, R.: Kinetics, products, and mechanisms of secondary organic aerosol formation, Chem. Soc. Rev., 41, 6582-6605, https://doi.org/10.1039/C2CS35122F, 2012. 